Article

\title{
Effects of Small-Scale Gold Mining Tailings on the Underwater Light Field in the Tapajós River Basin, Brazilian Amazon
}

\author{
Felipe de Lucia Lobo ${ }^{1,2, *}$, Maycira Costa ${ }^{1, *}$, Evlyn Márcia Leão De Moraes Novo ${ }^{2, *}$ \\ and Kevin Telmer 1,3,* \\ 1 Spectral Lab, Department of Geography, University of Victoria, 3800 Finnerty Road, Victoria, \\ BC V8P 5C2, Canada \\ 2 Remote Sensing Division, National Institute for Space Research (INPE), Av. dos Astronautas 1758, \\ Jardim da Granja 12227-010, São José dos Campos, Brazil \\ 3 Artisanal Gold Council, 101-732 Cormorant St., Victoria, BC V8W 4A5, Canada \\ * Correspondence: felipe.lobo@inpe.br (F.d.L.L.); maycira@uvic.ca (M.C.); evlyn.novo@inpe.br (E.M.L.D.M.N.); \\ ktelmer@artisanalgold.org (K.T.); Tel.: +55-12-3208-6810 (F.d.L.L.); +1-250-7217334 (M.C.); \\ +55-(12)-3208-6443 (E.M.L.D.M.N.); +1-(250)-590-9433 (K.T.)
}

Received: 15 June 2017; Accepted: 15 August 2017; Published: 21 August 2017

\begin{abstract}
Artisanal and Small-scale Gold Mining (ASGM) within the Amazon region has created several environmental impacts, such as mercury contamination and changes in water quality due to increased siltation. This paper describes the effects of water siltation on the underwater light environment of rivers under different levels of gold mining activities in the Tapajós River Basin. Furthermore, it investigates possible impacts on the phytoplankton community. Two field campaigns were conducted in the Tapajós River Basin, during high water level and during low water level seasons, to measure Inherent and Apparent Optical Properties (IOPs, AOPs), including scattering $(b)$ and absorption $(a)$ coefficients and biogeochemical data (sediment content, pigments, and phytoplankton quantification). The biogeochemical data was separated into five classes according to the concentration of total suspended solids (TSS) ranging from $1.8 \mathrm{mg} \cdot \mathrm{L}^{-1}$ to $113.6 \mathrm{mg} \cdot \mathrm{L}^{-1}$. The in-water light environment varied among those classes due to a wide range of concentrations of inorganic TSS originated from different levels of mining activities. For tributaries with low or no influence of mining tailings (TSS up to $6.8 \mathrm{mg} \cdot \mathrm{L}^{-1}$ ), waters are relatively more absorbent with $b: a$ ratio of 0.8 at $440 \mathrm{~nm}$ and $b_{660}$ magnitude of $2.1 \mathrm{~m}^{-1}$. With increased TSS loadings from mining operations (TSS over $100 \mathrm{mg} \cdot \mathrm{L}^{-1}$ ), the scattering process prevails over absorption (b:a ratio of 10.0 at $440 \mathrm{~nm}$ ), and $b_{660}$ increases to $20.8 \mathrm{~m}^{-1}$. Non-impacted tributaries presented a critical depth for phytoplankton productivity of up to $6.0 \mathrm{~m}$ with available light evenly distributed throughout the spectra. Whereas for greatly impacted waters, attenuation of light was faster, reducing the critical depth to about $1.7 \mathrm{~m}$, with most of the available light comprising of red wavelengths. Overall, a dominance of diatoms was observed for the upstream rivers, whereas cyanobacteria prevailed in the low section of the Tapajós River. The results suggest that the spatial and temporal distribution of phytoplankton in the Tapajós River Basin is not only a function of light availability, but rather depends on the interplay of factors, including flood pulse, water velocity, nutrient availability, and seasonal variation of incoming irradiance. Ongoing research indicates that the effects of mining tailings on the aquatic environment, described here, are occurring in several rivers within the Amazon River Basin.
\end{abstract}

Keywords: optical properties; biogeochemical data; inorganic particles; light attenuation; critical depth 


\section{Introduction}

The increase in the gold price over the past 10 years has stimulated small-scale gold mining in Africa, Asia, and South America, resulting in an annual production of around 400 tonnes of gold by roughly 16 million miners [1]. Despite the contribution of approximately $12 \%$ of total global gold production [2], artisanal gold mining is known to have many negative environmental impacts [3], and most of these activities are illegal [4]. Mercury contamination [2,5,6], geomorphological changes [7], and water siltation are among the primary direct impacts of small-scale gold mining [8]. Water siltation caused by gold mining is commonly reported throughout the world (such as Indonesia [2] in Asia, Ghana [9] in Africa, and French Guyana [10] and Peru [11] in South America) due to the fact that most of the mining activities occur in rivers or at their margins [12]. In the Brazilian Amazon, for example, sediments from mining tailings in streams and rivers may vary between one and two tonnes per gram of gold produced [13]. One of the major impacts of water siltation is the increase in light attenuation by suspended particles, which can directly affect phytoplankton productivity by limiting the availability of Photosynthetic Active Radiation (PAR), and indirectly contribute to changes in biodiversity within rivers, including plankton [10], macroinvertebrates [14], and fish [15]. Specific to the Amazon Basin, a major reduction in phytoplankton density has been documented in Batata Lake due to a gain in suspended matter caused by mining activity [16]. Guenther and Bozelli [17] have attributed this reduction to a decrease in growth rates caused by high light attenuation due to increased suspended matter derived from mining activities. Moreover, Tudesque et al. [10] have reported changes in phytoplankton community with a rise in the proportion of benthic diatoms due to increase in water siltation in streams impacted by small-scale gold mining in French-Guiana.

While a few studies have shown the impacts on underwater light conditions caused by mining tailings [16,17], the quantification of the impacts on the spectral underwater light environment in Amazonian waters is still lacking. Understanding the underwater light environment, more specifically the total scalar irradiance, $E_{0}$, is fundamentally important since it comprises the total spectral energy available for photosynthesis in the interval between 400 and $700 \mathrm{~nm}$, which in turn allows for comprehension of the phytoplankton absorption efficiency [18]. For example, an underwater light field rich in blue-green light will favor phytoplankton groups that have pigments that absorb light in the blue-green spectra [19].

This research focuses on defining the impact of gold mining tailings in the light environment of the Tapajós River Basin, and associated phytoplankton communities' diversity. Specifically, this study provides the following: (1) an evaluation of the effects of sediment loading on the underwater light environment of impacted and non-impacted rivers; and (2) evaluation of the relationship between light attenuation caused by water siltation and the critical depth for phytoplankton communities. To address these objectives, biogeochemical and in situ optical measurements, including Inherent Optical Properties (IOPs) and Apparent Optical Properties (AOPs), were collected during two field campaigns addressing high and low water conditions. Despite the strong emphasis on underwater light fields, this paper also provides a partial discussion on the distribution of phytoplankton communities and other important factors, such as hydrological regime, current velocity, and depth.

\section{Material and Methods}

\subsection{Study Area}

The Tapajós River Basin includes the largest small-scale gold mining area in the world $\left(28,186 \mathrm{~km}^{2}\right)$, which has been intensively mined, either using water-jets to remove top soil layers, or using small boats called 'balsas' that take the sediment from the bottom of the rivers using suction and gravity processes [20,21]. Currently, more than 300 small-scale mines (most without mining licenses) with the participation of more than 50,000 miners produce gold within the Artisanal Gold Mining District. This district was created in 1983 to support gold miners and overlaps three main sub-basins: Novo, Crepori, and Tocantinzinho (abbreviated Tocantins) (Figure 1). 


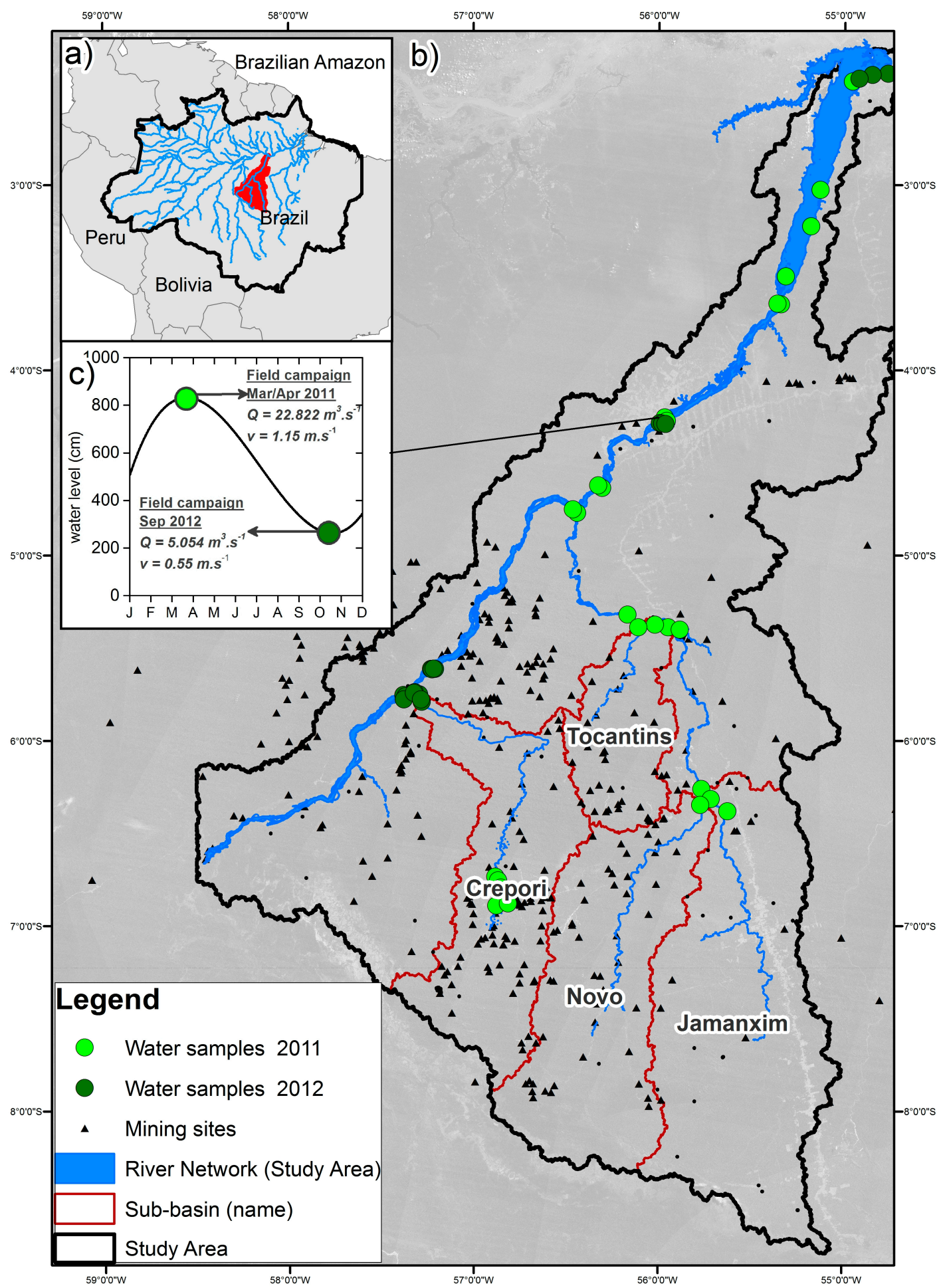

Figure 1. Study area. (a) Overview of the Brazilian Amazon. (b) Tapajós River Basin in the Brazilian Amazon showing the main tributaries, sample sites (see Section 4.1), deforestation [22] (light grey), and mines [23]. (c) Water flow $(Q)$ and water speed $(v)$ are also shown for the Tapajós River at the Itaituba City region during high and low water level.

The lower section of the Tapajós River Basin covers about 130,370 km² (Figure 1) and drains mostly lixiviated Pre-Cambrian rocks, which results in water that is transparent/greenish with low amounts of suspended solids, so-called "clearwaters" [24,25]. The river basin can generally be separated into 
two geomorphological sections: the upstream riverine section (lotic system) from headwaters down to the Aveiro City region; and the downstream section (semi-lentic system-locally called Tapajós Lake), from Aveiro City to the mouth of the river where it runs into the Amazon River (Figure 1).

The downstream river section is relatively wide $(10-15 \mathrm{~km})$ with low water speed, creating a semi-lacustrine environment, able to support phytoplankton growth. Chlorophyll- $a(\operatorname{chl}-a)$ concentrations vary from 5.0 to $25.1 \mu \mathrm{g} \cdot \mathrm{L}^{-1}$ [26,27], and cyanobacteria blooms related to urban-derived diffuse nutrient input at the margins of the Tapajós mouth (Santarém) have been reported [28]. In this section of the river, total suspended sediments (TSS) are composed primarily of fine matter discharged from upstream [29-31] reaching concentrations up to $4.1 \mathrm{mg} \cdot \mathrm{L}^{-1}$ during rising and receding water levels [32]. In the Tapajós, for example Costa et al. [32] observed, on average, lower $a_{c d o m}$ absorption $\left(a_{\text {cdom }(440)}=3.2 \mathrm{~m}^{-1}\right)$ than values measured in black water rivers of the Amazon $\left(8.6 \mathrm{~m}^{-1}\right)$. As a result of the low TSS and $a_{c d o m}$, the diffuse attenuation coefficient $\left(K_{d}\right.$ PAR) was reported at around $2.0 \mathrm{~m}^{-1}$ in both rising and falling periods, whereas for black and white Amazonian rivers, $K_{d}$ increases to 3.7 and $5.1 \mathrm{~m}^{-1}$, respectively [32].

Information about biogeochemistry [21,33] and hydrological optics of the upstream section of the river is rare. As opposed to the semi-lentic conditions of the Tapajós Lake section, the upstream section starting from Aveiro City (Figure 1) is narrower (2-4 km), with a strong advection current [30]. In such systems, plankton development is likely suppressed by the low residence time and turbulence of running water [34]. As a result of low photosynthetic production, the suspended sediment content is composed mostly of allochthonous matter, such as quartz, plant debris, and clay clusters, rather than autochthonous matter $[33,35]$.

\subsection{Methods}

The methodology of this study consisted of two components (Figure 2): (1) acquisition of in situ optical (Table 1) and biogeochemical data at high (2011) and low (2012) water levels to define the in-water light environment; and (2) evaluation of the critical depth for phytoplankton productivity based on the available light.

\section{a) Sampling}

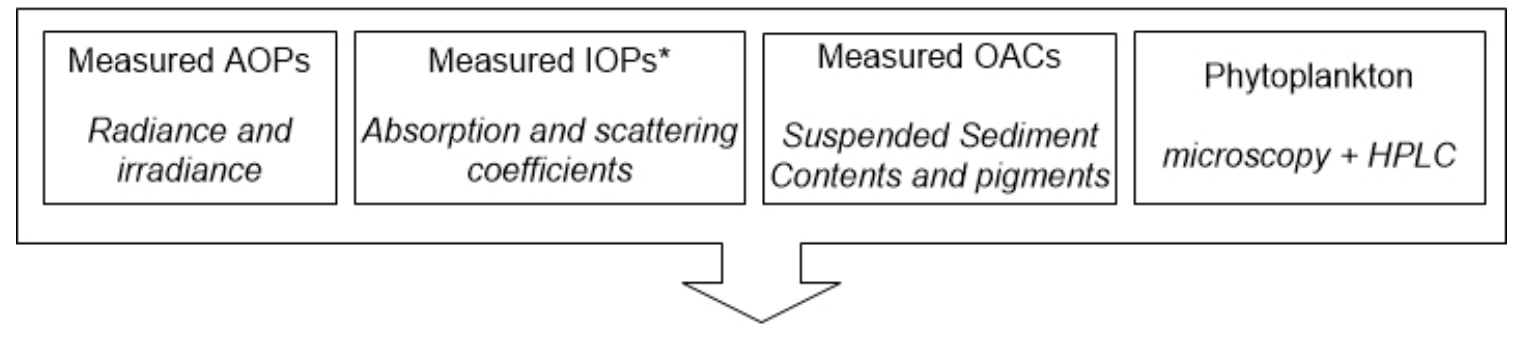

b) Light availability and phytoplankton

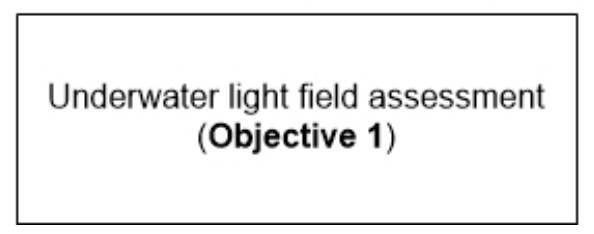

Light Availability and critical depth for phytoplankton (Objective 2)

Figure 2. The methodology comprises (a) field campaigns for acquisition of optical properties and biogeochemical measurements to quantify underwater light field changes from non-impacted to impacted rivers; (b) assessment of light availability for phytoplankton, including critical depth analyses. 
Table 1. Compilation of all optical parameters used in this paper, including respective symbol, unit, and calculation formula.

\begin{tabular}{cccc}
\hline Inherent Optical Property & Symbol & Unit & Formula \\
\hline Attenuation coefficient & $c(\lambda)$ & $\mathrm{m}^{-1}$ & Equation (1) \\
Absorption coefficient & $a(\lambda)$ & $\mathrm{m}^{-1}$ & Equation (2) \\
Scattering coefficient & $b(\lambda)$ & $\mathrm{m}^{-1}$ & Equation (3) \\
Backscattering coefficient & $b_{b}(\lambda)$ & $\mathrm{m}^{-1}$ & Equation (4) \\
\hline Apparent Optical Property & & & \\
\hline Upwelling radiance & $L_{u}$ & $\mathrm{~W} \cdot \mathrm{m}^{-2} \cdot \mathrm{sr}^{-1}$ & - \\
Downwelling irradiance & $E_{d}$ & $\mathrm{~W} \cdot \mathrm{m}^{-2}$ & - \\
Downwelling irradiance (above water) & $E_{d}\left(0^{+}\right)$ & $\mathrm{W} \cdot \mathrm{m}^{-2}$ & - \\
Upwelling irradiance & $E_{u}$ & $\mathrm{~W} \cdot \mathrm{m}^{-2}$ & Equation (5) \\
Scalar irradiance & $E_{o}$ & $\mathrm{~W} \cdot \mathrm{m}^{-2}$ & Equation (7) \\
Downwelling irradiance attenuation coefficient & $K_{d}$ & $\mathrm{~m}{ }^{-1}$ & Equation (6) \\
Normalized scalar irradiance & $\bar{E}_{o}=E o / E d$ & - & Equation (8) \\
Critical depth & $Z_{c}(P A R)$ & $\mathrm{m}$ & Equation (9) \\
\hline
\end{tabular}

\subsubsection{Sampling}

Two field campaigns were conducted in the Tapajós River Basin to measure IOPs, AOPs, and biogeochemical data in March/April 2011 during high water level (27 sample points) and September 2012 during low water level periods (13 sample points, no IOPs data due to loss of ac-S optical equipment in the Tapajós River at the beginning of the field work) (see Figure 1 for sample site locations). Sample sites were distributed along the Tapajós River and main tributaries, which correspond to known locations of mined (Crepori, Tocantins, and Novo) and non-mined tributaries (Jamanxim River). As a side note, logistically, fieldwork in this remote region of the Amazon was extremely difficult due to the size and weight of the optical sensors and other field and analytical equipment, as well as issues related to security due to local land conflicts.

\subsubsection{Biogeochemical Data}

For each sampled site $(n=40)$, two water samples (at least $500 \mathrm{~mL}$ sample volume) were taken at a depth of $0.3 \mathrm{~m}$ and at $Z_{1 \%}$ (depth where downwelling irradiance reaches $1 \%$ of surface irradiance) to determine TSS concentrations according to the gravimetric method [36]. The surface $(0.3 \mathrm{~m})$ and depths at $Z_{1 \%}$ were chosen to represent the water column where phytoplankton productivity can occur [34]. For each water sample, triplicates of pre-weighed GF/F $(0.7 \mu \mathrm{m})$ filters were preserved in cold, dark environments until laboratory analysis was conducted. After TSS analysis, half of those filters were used for particulate organic carbon (POC) determination according to the high-temperature combustion method with TOC-V analyzer (Shimadzu Inc., Guelph, ON, Canada) [37]. The other filters were used in determining the percentage of the organic content present by applying the Loss On Ignition (LOI) technique [36]. Water samples $(500 \mathrm{~mL})$ were also filtered with GF/F $(0.7 \mu \mathrm{m})$ for determination of chl-a and auxiliary pigments by HPLC (High-Performance Liquid Chromatography) [36]. The pigments on the filters were extracted with 90\% acetone, centrifuged, and analyzed in HPLC (Dionex P680) within $24 \mathrm{~h}$ after extraction to avoid pigment degradation [38].

Discrete surface water samples were taken from a subset ( $n=15$ including both campaigns) of the total sampled locations in mined and non-mined tributaries for quantitative and qualitative analyses of phytoplankton populations using the microscopy settling technique [39]. The units, corresponding to cells, colonies, and filaments, were enumerated to at least 100 specimens of the most frequent species at $400 \times$ [40]. Specific phytoplankton biovolume $\left(\mathrm{mm}^{3} \mathrm{~L}^{-1}\right)$ was estimated according to Hillebrand et al. [41]. 


\subsubsection{Optical Data}

Inherent optical properties (IOP) measurements were only acquired during the high water level period (April 2011, $n=27$ ) due to logistical problems (previously explained). Total beam attenuation $c(\lambda)$ and total absorption $a(\lambda)$ coefficients were measured in situ with a WetLabs (Philomath, Oregon) ac-S instrument at 80 wavelengths from 390 to $750 \mathrm{~nm}$. Total beam attenuation coefficient $c(\lambda)$ is the sum of the total absorption $a(\lambda)$ and total scattering coefficient $b(\lambda)$. The absorption coefficient is defined as the sum of the absorption coefficients by water $a_{w}(\lambda)$, particulate material $a_{p}(\lambda)$, and coloured dissolved organic matter $a_{c d o m}(\lambda)$ [42]. Similarly, the total scattering is the sum of its component scattering coefficient of water $b_{w}(\lambda)$ and particulate material $b_{p}(\lambda)$, with the general assumption that scattering due to CDOM is negligible [42].

$$
\begin{gathered}
c(\lambda)=a(\lambda)+b(\lambda) \\
a(\lambda)=a_{w}(\lambda)+a_{c d o m}(\lambda)+a_{p}(\lambda) \\
b(\lambda)=b_{w}(\lambda)+b_{p}(\lambda)
\end{gathered}
$$

The ac-S output was calibrated using ultra-clean water from the Barnstead E-pure water purification system before and after field campaigns to minimize measurement deviation caused by sensor transportation. The output was also corrected for temperature and scattering in the absorption tube using the manufacturer protocol [43]. The $a_{c d o m}(\lambda)$ coefficient over PAR was acquired after filtering sampled water with a Pall $0.2 \mu \mathrm{m}$ sterile filter. Spectral measurements of the filtered water were taken in situ with the Ocean Optics UV-4000 equipment [44]. The measured absorbance was firstly corrected for blank offset measured with deionized water and secondly converted to $a_{c d o m}(\lambda)$ according to Kirk [18]. Attached in the same cage along with ac-S, the Environmental Characterization Optics-Backscattering (ECO-BB) by Wetlabs $@$ measured particle backscattering $\left(b_{b p}(\lambda)\right)$ at three wavelengths $(470,532$, and $660 \mathrm{~nm})$. For each wavelength, $b_{b p}(\lambda)$ was determined as follows:

$$
b_{b p}(\lambda)=2 \pi \times x \times \beta_{b p}\left(117^{\circ}\right),
$$

where $b_{b p}(\lambda)$ is the particulate backscattering coefficient, $\beta_{b}\left(117^{\circ}, \lambda\right)$ is the volume scattering function given a wavelength $(\lambda)$ for a specific angle $\left(117^{\circ}\right)$, and $x$ is 1.1 as determined by Boss et al. [45].

Apparent Optical Properties (AOPs) were measured using two profiling Satlantic hyperspectral radiometers and one above-water hyperspectral radiometer during both field campaigns $(n=40)$. The radiometers (HyperPro-3000) measure in-water downwelling irradiance $\left(E_{d}\left(0^{-}, \lambda\right)\right)$ and upwelling radiance $\left(L_{u}\left(0^{-}, \lambda\right)\right)$, as well as above-water downwelling surface irradiance $\left(E_{d}\left(0^{+}, \lambda\right)\right)$ in the interval from 396 to $800 \mathrm{~nm}$ with a resolution of $10 \mathrm{~nm}$. Radiometric data was processed using Satlantic's Prosoft [46]. After being corrected and binned to depth intervals, $L_{u}\left(0^{-}, \lambda\right)$ values were then used to calculate upward irradiance $E_{u}\left(0^{+}, \lambda\right)$ as follows:

$$
E_{u}\left(0^{+}, \lambda\right)=4.5 \times L_{u}\left(0^{-}, \lambda\right) \times\left(1-\rho(\lambda, \theta) / n_{w}^{2}(\lambda)\right)
$$

where $\rho(\lambda, \theta)$ is reflective index (0.021) and $n_{w}^{2}$ is refractive index (1.34) [42].

Further, diffuse attenuation coefficient $K_{d}(\lambda)$ was calculated as [18]:

$$
K_{d}(\lambda)=\ln \left(\frac{E_{d} 2(\lambda)}{E_{d} 1(\lambda)}\right) \frac{1}{\Delta z}
$$

where $E_{d} 2(\lambda)$ is the downwelling irradiance at depth 2 , and $E_{d} 1(\lambda)$ is the downwelling irradiance at depth 1 , and $\Delta z$ is the depth difference between these two measurements.

\subsubsection{Critical Depth for Photosynthesis}

Given that phytoplankton cells can utilize irradiance from all directions, the quantity and quality (spectral distribution) of the light available for photosynthesis in the aquatic environment, underwater total scalar irradiance, $E_{o}\left(0^{-}, \lambda\right)(\lambda=400-700 \mathrm{~nm})$, is defined as follows [18]:

$$
E_{o}\left(0^{-}, \lambda\right)=E_{d}\left(0^{-}, \lambda\right)+E_{u}\left(0^{-}, \lambda\right),
$$


where $E_{u}\left(0^{-}, \lambda\right)$ and $E_{d}\left(0^{-}, \lambda\right)$ are upwelling and downwelling irradiance, respectively.

In order to compare the light availability amongst the five classes and minimize the effect of variations in atmospheric conditions during each measurement, scalar irradiance $\left(E_{o}\right)$ was normalized by downward irradiance measured above water $\left(E_{d}{ }^{+}\right)$resulting in $\overline{E_{0}}$, as follows:

$$
\overline{E_{o}}\left(0^{-}, \lambda\right)=E_{o}\left(0^{-}, \lambda\right) / E_{d}\left(0^{+}, \lambda\right)
$$

Once the $E_{o}\left(0^{-}, 400-700 \mathrm{~nm}\right)$ was calculated, the critical depth for phytoplankton was estimated for the different classes of water. Critical depth, $\left(Z_{c}\right)$, is the depth at which the photosynthetic production by a phytoplankton community is equal to the energy loss on processes such as respiration. In other words, given optimum conditions of nutrient concentration, $Z_{c}$ is the depth at which irradiance is the minimum necessary for photosynthesis. $Z_{c}$ is calculated as follows [18]:

$$
Z_{c}(P A R)=\frac{\ln E_{o}\left(0^{-}, P A R\right)-\ln E_{c}(P A R)}{K_{o}(P A R)},
$$

where $E_{o}\left(0^{-}, \mathrm{PAR}\right)$ is the sub-surface scalar irradiance modeled by Hydrolight; $K_{o}(\mathrm{PAR})$ is the average scalar attenuation coefficient for PAR from the surface to $Z_{1 \%}$ (similar to Equation (6)), and $E_{c}(\mathrm{PAR})$ is the species-specific compensation irradiance. To calculate $Z_{c}$, we adopted $E_{c}(\mathrm{PAR})$ based on the freshwater phytoplankton minimum light requirement described by Deblois et al. [47]. The authors reported that Chlamydomonas sp. (Chlorophyta) (identified in this study) shows a growth rate close to zero when exposed to irradiance of $14 \mu \mathrm{Em}^{-2} \mathrm{~s}^{-1}$, whereas other species, such as Aulacoseira granulate (diatom) and Cryptomonas obovata (Cryptophyta), present a growth rate of up to 0.2 divisions/day when exposed to the same light regime. For freshwater phytoplankton communities, a minimum $E_{c}$ of $14 \mu \mathrm{Em}^{-2} \mathrm{~s}^{-1}$ was defined as a general compensation irradiance as described in Deblois et al. [47] and therefore used as input to calculate $Z_{c}$ in Equation (9).

Furthermore, analyses of critical depth must take into account the depth of the mixing layer $\left(Z_{m}\right)$. If the depth of the mixed layer is smaller than or equal to $Z_{c}$, then there is sufficient light to drive net production and phytoplankton growth [48]. On the other hand, if $Z_{m}$ is greater than $Z_{c}$, light can become a limiting factor for net production in deeper layers. In river systems, where high current velocity and turbulence mixes the water column homogeneously, $Z_{m}$ usually coincides with the total water depth (Z) [49]. In turbid and deep rivers such as the Amazon, phytoplankton is only exposed to light for a short period within the upper layers. This low light exposure can reduce phytoplankton productivity, as indicated by Dustan [50]. For oceans and lakes, thermal stratification can occur, reducing the mixed layer to shallower depths than $Z_{c}$ and favoring phytoplankton growth and bloom conditions [49].

\subsubsection{Data Analysis}

The analyses of collected data were conducted in four steps: (1) Sampled points were organized into five classes of TSS concentration, corresponding to different levels of mining influence from low to high mining tailing influence; (2) TSS classes were submitted to non-parametric test to verify the significance difference between them at $p<0.10$; (3) Once the TSS classes were defined and tested, a full optical and biogeochemical characterization were conducted including phytoplankton, pigments, IOPs, and AOPs; and (4) In order to verify the contribution of discharged sediment derived from mining activities to the optical properties (IOPs and AOPs), Pearson's correlations between sediment content and optical properties were performed $(p<0.05)$.

\section{Results}

\subsection{Biogeochemical Data}

The biogeochemical data were separated into five preliminary classes according to the concentration of total suspended matter aiming to facilitate the interpretation of the results (Table 2). The definition of classes was based on prior knowledge of the level of mining impact on the sampled 
rivers and statistical tests for significant differences on TSS (non-parametric Mann-Whitney U Tests; $p<0.10$, Appendix A). The non-parametric test confirmed the significant difference among the five classes of TSS (Table 2), which displays considerable changes in their spatial and seasonal distribution along the Tapajós River and main tributaries (Figure 3).

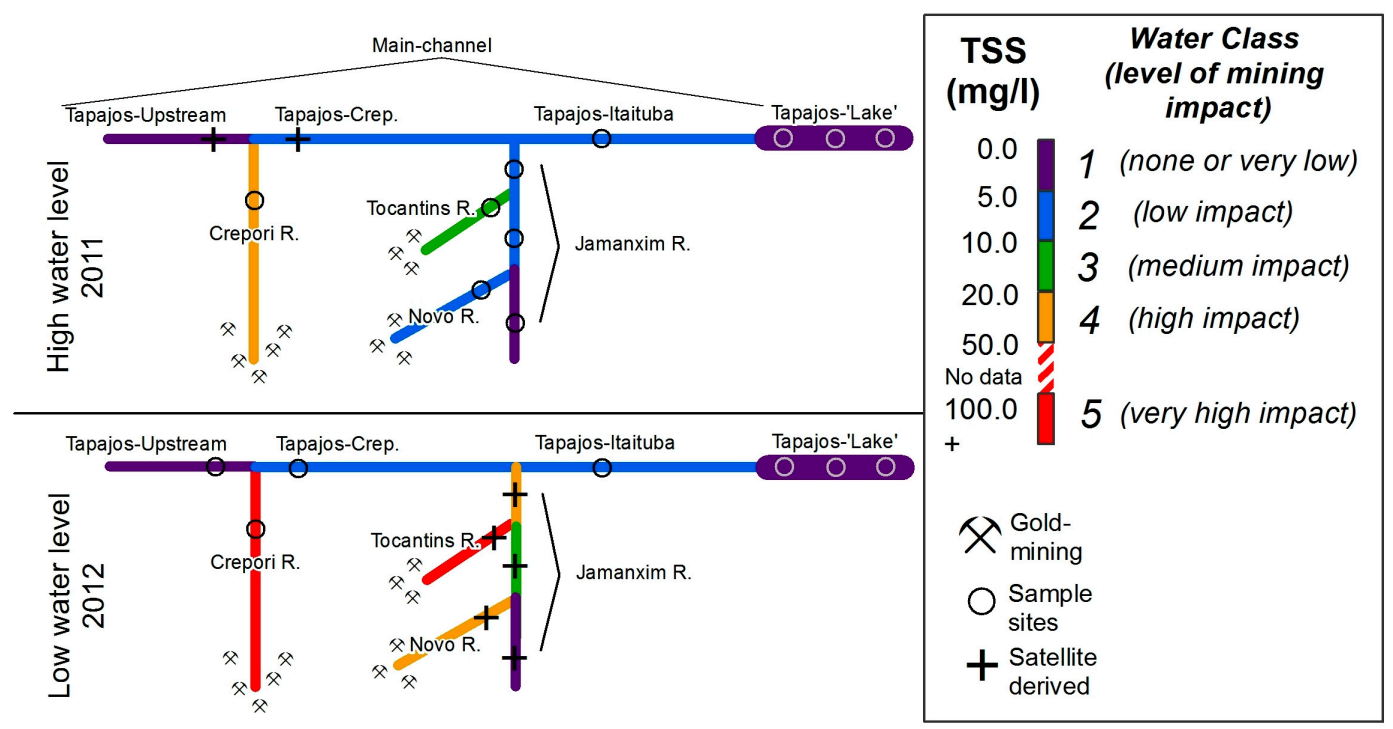

Figure 3. Schematic representation of TSS concentrations along the Tapajós River and its tributaries for high (April 2011) and low (September 2012) water levels. The river and its tributaries were classified according to TSS $\left(\mathrm{mg} \cdot \mathrm{L}^{-1}\right)$ concentrations. TSS for Tocantins, Novo, and Jamanxim rivers during the low water season were retrieved from Landsat surface reflectance (red band) [51]. The level of mining impact is an arbitrary classification considering the intensity level of mining and mining area distribution. Not to scale.

Class 1 includes upstream Jamanxim (Jamanxim 1), Tapajós-Upstream, and the Tapajós Lake section of the river (Figure 3), corresponding to a total of 17 samples with TSS concentrations of up to $5.0 \mathrm{mg} \cdot \mathrm{L}^{-1}$. Although all samples belong to clear water [25,52], their hydrodynamic characteristics vary from lotic upriver to a semi-lentic system at the Tapajós Lake region. For that reason, they will be presented and discussed separately.

Sampled during high water period, upstream Jamanxim River site showed $a_{\text {cdom (440) }}$ of $3.2 \mathrm{~m}^{-1}$ and maximum values of TSS of $3.6 \mathrm{mg} \cdot \mathrm{L}^{-1}$ with $37 \%$ of organic content (POC $\left.=17 \%\right)$. Tapajós-Upstream (Figure 3) sampled during low water period showed similar suspended sediment and organic content concentrations as those of upstream Jamanxim, but higher average chl-a concentration $\left(1.1 \mu \mathrm{g} \cdot \mathrm{L}^{-1}\right)$. At the lower section of the Tapajós Lake, TSS values of $2.0 \mathrm{mg} \cdot \mathrm{L}^{-1}$ were measured during the low water level period and approximately $3.0 \mathrm{mg} \cdot \mathrm{L}^{-1}$ in the high water period. The organic content in the Tapajós Lake was consistently higher than that in upstream tributaries and Tapajós-Upstream during both seasons, with an average of $50 \%$ (POC $\sim 13 \%$ ). Differences were not observed for $a_{c d o m}(440)$. chl-a followed values observed at upstream Tapajós River, with concentrations up to $1.4 \mu \mathrm{g} \cdot \mathrm{L}^{-1}$.

Class 2 includes 15 sites with low impact mining activities, in which TSS concentrations vary from 5.0 to $10.0 \mathrm{mg} \cdot \mathrm{L}^{-1}$, and comprises water samples taken at the Jamanxim River, after the confluence of Novo (Jamanxim 2) and Tocantins rivers (Jamanxim 3), acquired during the high water period, and samples of the Tapajós River at Itaituba (Tapajós-Itaituba), sampled during both periods (Figure 3). TSS was relatively higher $\left(6.3 \mathrm{mg} \cdot \mathrm{L}^{-1}\right.$ on average) than in Class $1\left(3.3 \mathrm{mg} \cdot \mathrm{L}^{-1}\right)$, followed by decreased organic and POC content to $24 \%$ and $9 \%$, respectively. On the other hand, $a_{\text {cdom (440) }}\left(3.2 \mathrm{~m}^{-1}\right)$ values were similar for both classes. The average chl-a concentration within Class 2, however, was higher $\left(1.1 \mu \mathrm{g} \cdot \mathrm{L}^{-1}\right)$ at the Tapajós-Itaituba river section than at the tributaries $\left(0.1 \mu \mathrm{g} \cdot \mathrm{L}^{-1}\right.$ in average $)$. 
Table 2. Values of suspended solids, chl-a, and optical properties of the water classes represented in Figure 3. * IOPs for low water samples were estimated based on linear regressions established for the measurements taken during the high water period. \& Parameters related to photic zone for phytoplankton productivity. Critical depth $\left(Z_{c}\right)$ and depth where scalar irradiance reaches $1 \%$ of the incoming light $\left(Z_{1 \%}\right)$ are approximately the same values.

\begin{tabular}{|c|c|c|c|c|c|c|c|c|c|c|c|c|c|c|c|c|c|c|c|c|c|}
\hline & \multirow{2}{*}{ Parameter (nm) } & \multirow{2}{*}{ Unit } & \multicolumn{4}{|c|}{ Class 1} & \multicolumn{4}{|c|}{ Class 2} & \multicolumn{3}{|c|}{ Class 3} & \multicolumn{4}{|c|}{ Class 4} & \multicolumn{4}{|c|}{ Class 5} \\
\hline & & & Min & $\operatorname{Max}$ & $\begin{array}{c}\text { Average } \\
(n=17)\end{array}$ & SD & Min & Max & $\begin{array}{c}\text { Average } \\
(n=15)\end{array}$ & SD & Min & $\operatorname{Max}$ & $\begin{array}{c}\text { Average } \\
(n=2)\end{array}$ & Min & $\operatorname{Max}$ & $\begin{array}{c}\text { Average } \\
(n=3)\end{array}$ & SD & Min & Max & $\begin{array}{c}\text { Average } \\
(n=3)\end{array}$ & SD \\
\hline \multirow{4}{*}{$\begin{array}{l}\text { Particulate } \\
\text { Matter }\end{array}$} & TSS & $\mathrm{mg} \cdot \mathrm{L}^{-1}$ & 1.8 & 4.2 & 3.3 & 0.7 & 5.6 & 6.8 & 6.3 & 0.5 & 13.4 & 14.7 & 14.0 & 33.4 & 35.8 & 35.7 & 2.3 & 111.1 & 113.6 & 111.3 & 2.1 \\
\hline & Org. Matter & $\%$ of TSS & 24.0 & 58.0 & 35.0 & 11.0 & 16.0 & 28.0 & 24.0 & 4.0 & 11.0 & 16.0 & 13.0 & 12.0 & 14.0 & 12.0 & 1.0 & 2.0 & 2.0 & 2.0 & 1.0 \\
\hline & POC & $\%$ of TSS & 10.0 & 28.0 & 15.0 & 6.0 & 7.0 & 10.0 & 9.0 & 1.0 & 4.0 & 5.0 & 4.0 & 3.0 & 3.0 & 3.0 & & 2.0 & 2.0 & 2.0 & \\
\hline & chl-a & $\mu \mathrm{g} \cdot \mathrm{L}^{-1}$ & 0.0 & 1.2 & 0.7 & 0.5 & 0.1 & 1.1 & 0.5 & 0.4 & 1.1 & 0.0 & 0.6 & 0.1 & 0.1 & 0.1 & 0.0 & 0.6 & 0.7 & 0.7 & 0.1 \\
\hline \multirow{4}{*}{$\begin{array}{c}\text { Measured } \\
\text { IOPs * }\end{array}$} & $a_{\text {CDOM (440) }}$ & $\mathrm{m}^{-1}$ & 2.5 & 3.2 & 2.9 & 0.3 & 2.9 & 3.5 & 3.2 & 0.2 & 3.0 & 3.1 & 3.1 & 2.0 & 2.1 & 2.1 & 0.1 & 2.4 & 2.8 & 2.5 & 0.3 \\
\hline & $a_{p(440)}$ & $\mathrm{m}^{-1}$ & 0.4 & 1.8 & 1.5 & 0.4 & 1.7 & 2.1 & 1.8 & 0.2 & 2.0 & 2.0 & 2.0 & 2.6 & 3.1 & 2.9 & 0.3 & 6.1 & 6.2 & 6.1 & 0.1 \\
\hline & $b_{p}(660)$ & $\mathrm{m}^{-1}$ & 1.3 & 2.8 & 2.1 & 0.6 & 3.2 & 4.4 & 3.7 & 0.4 & 7.7 & 8.6 & 8.2 & 18.7 & 21.3 & 20.8 & 1.9 & 64.3 & 65.5 & 64.4 & 1.1 \\
\hline & $b_{b p}(660)$ & $\mathrm{m}^{-1}$ & 0.1 & 0.1 & 0.1 & 0.0 & 0.1 & 0.2 & 0.1 & 0.0 & 0.3 & 0.3 & 0.3 & 0.6 & 0.6 & 0.6 & 0.0 & 1.9 & 2.0 & 1.9 & 0.0 \\
\hline \multirow{8}{*}{$\begin{array}{l}\text { Measured } \\
\text { AOPs }\end{array}$} & $K_{d(-0)(440)}$ & $\mu \mathrm{E}^{-2} \cdot \mathrm{s}^{-1}$ & 1.3 & 6.9 & 3.4 & 1.9 & 1.7 & 7.2 & 4.8 & 1.6 & 3.5 & 6.6 & 5.0 & 10.2 & 10.4 & 10.3 & 0.1 & 13.5 & 14.2 & 13.9 & 0.4 \\
\hline & $K_{d(-0)(560)}$ & $\mu \mathrm{E}^{-2} \cdot \mathrm{s}^{-1}$ & 0.6 & 2.8 & 1.4 & 0.8 & 0.8 & 3.1 & 2.1 & 0.7 & 1.9 & 3.0 & 2.4 & 4.5 & 4.8 & 4.6 & 0.2 & 8.0 & 9.0 & 8.7 & 0.6 \\
\hline & $K_{d(-0)(660)}$ & $\mu \mathrm{E}^{-2} \cdot \mathrm{s}^{-1}$ & 0.7 & 1.9 & 1.2 & 0.4 & 0.9 & 2.2 & 1.6 & 0.4 & 1.7 & 1.9 & 1.8 & 3.0 & 3.4 & 3.2 & 0.2 & 6.0 & 6.3 & 6.2 & 0.2 \\
\hline & $K_{d}(-0$, PAR $)$ & $\mathrm{m}^{-1}$ & 1.0 & 2.8 & 2.0 & 0.9 & 1.1 & 3.7 & 2.7 & 1.1 & 3.2 & 3.8 & 3.5 & 6.0 & 6.2 & 6.0 & 0.2 & 9.0 & 9.8 & 9.6 & 0.5 \\
\hline & $E_{o(0.3 \mathrm{~m})} / E_{d^{+}}{ }^{(440)}$ & $\mu \mathrm{E}^{-2} \cdot \mathrm{s}^{-1}$ & 1.6 & 2.3 & 1.9 & 0.3 & 1.5 & 2.2 & 1.8 & 0.3 & 0.9 & 1.7 & 1.3 & 0.6 & 0.8 & 0.7 & 0.1 & 0.4 & 0.5 & 0.4 & 0.3 \\
\hline & $E_{o}(0.3 \mathrm{~m}) / E_{d^{+}}^{+}(560)$ & $\mu \mathrm{E}^{-2} \cdot \mathrm{s}^{-1}$ & 4.8 & 5.4 & 5.1 & 0.3 & 4.4 & 5.2 & 4.7 & 0.4 & 3.3 & 3.9 & 3.6 & 1.9 & 2.3 & 2.1 & 0.2 & 1.0 & 1.4 & 1.2 & 0.2 \\
\hline & $E_{o(0.3 \mathrm{~m})} / E_{d^{+}}(660)$ & $\mu \mathrm{E}^{-2} \cdot \mathrm{s}^{-1}$ & 5.1 & 6.6 & 5.9 & 0.4 & 5.5 & 6.3 & 5.7 & 0.4 & 5.0 & 5.5 & 5.3 & 3.9 & 4.3 & 4.1 & 0.2 & 2.0 & 2.4 & 2.2 & 0.2 \\
\hline & $E_{O 1 \%}$ PAR & $\mu \mathrm{E} \cdot \cdot^{-2} \cdot \mathrm{s}^{-1}$ & 5.9 & 19.0 & 10.8 & 5.1 & 2.3 & 20.3 & 10.9 & 6.1 & 12.0 & 17.2 & 14.6 & 8.6 & 17.3 & 11.4 & 5.0 & 19.3 & 20.3 & 19.8 & 0.5 \\
\hline \multirow{3}{*}{$\begin{array}{l}\text { Photic } \\
\text { Zone \& }\end{array}$} & $\begin{array}{c}Z_{1 \%}=\sim Z_{c} \\
\text { (Chlamydomonas) }\end{array}$ & $\mathrm{m}$ & 3.8 & 7.1 & 5.2 & 1.1 & 2.9 & 5.3 & 4.0 & 0.8 & 3.6 & 3.9 & 3.8 & 2.3 & 2.9 & 2.4 & 0.4 & 1.6 & 1.8 & 1.7 & 0.1 \\
\hline & $Z_{m} / Z_{c}$ & - & 0.4 & 2.5 & 1.5 & 0.7 & 1.0 & 2.1 & 1.5 & 0.4 & 1.3 & 1.8 & 1.5 & 1.8 & 2.3 & 2.1 & 0.3 & 1.2 & 1.3 & 1.2 & 0.1 \\
\hline & $\operatorname{depth} Z_{m}$ & $\mathrm{~m}$ & 3.1 & 15.3 & 7.4 & 3.8 & 4.9 & 7.2 & 5.6 & 0.9 & 5.0 & 6.5 & 5.8 & 5.1 & 5.1 & 5.1 & 0.1 & 2.1 & 2.0 & 2.1 & 0.1 \\
\hline
\end{tabular}


Class 3 includes tributaries subjected to gold mining at medium impact level with TSS concentration between 10.0 and $20.0 \mathrm{mg} \cdot \mathrm{L}^{-1}$, and is represented by samples taken in the Tocantins River during the high water period, and in the Tapajós River after receiving the Crepori River inflow (named Tapajós-Crepori) during low water level periods. Overall, $a_{c d o m}(440)$ were similar to those from previous classes, and organic matter decreased to $13 \%$ ( $\mathrm{POC}=4 \%$ ), indicating an increased influence of inorganic sediment input from mining tailings to the TSS when compared to Classes 1 and 2.

Class 4 and Class 5 represent rivers subjected to high level of mining activity and comprise samples of the Crepori River at the high and low water periods, respectively (Figure 3). During the high water level period, TSS concentration of approximately $33.0 \mathrm{mg} \cdot \mathrm{L}^{-1}$ was observed, whereas in the low water period, TSS increased to $111.0 \mathrm{mg} \cdot \mathrm{L}^{-1}$. Values for $a_{\text {cdom }}(440)$, however, were similar in both periods (2.1 and $2.5 \mathrm{~m}^{-1}$, respectively). The organic matter content for Class 4 (12\%) was not different from that observed in Class 3, but it decreased to 2\% for Class 5 due mainly to POC (Table 2). Regarding chl-a, Crepori River presented relatively higher chl-a $\left(0.7 \mu \mathrm{g} \cdot \mathrm{L}^{-1}\right)$ concentration during low water level when compared to samples acquired during high water level $\left(0.1 \mu \mathrm{g} \cdot \mathrm{L}^{-1}\right)$.

\subsection{Phytoplankton and Pigments}

Although samples were limited, phytoplankton microscopy analysis indicated a higher biovolume $\left(\mathrm{mm}^{3} \cdot \mathrm{L}^{-1}\right)$ during low water period compared to the high water period (Figure 4). Further, the upstream tributaries showed lower phytoplankton biovolume and dominance of diatoms and cryptomonads when compared to the Tapajós Lake section where most of the phytoplankton biovolume was higher (up to $6 \mathrm{~mm}^{3} \cdot \mathrm{L}^{-1}$ ) and dominated by cyanobacteria cells (Figure 4).

During low water period, the Crepori River and the Tapajós-Upstream sites showed biovolumes of approximately $0.7 \mathrm{~mm}^{3} \cdot \mathrm{L}^{-1}$ dominated by diatoms (Aulacoseira granulata, for example) and cryptophyceae (Cryptomonas sp.). A similar phytoplankton community was identified at Tapajós-Itaituba site, with an average biovolume of $1.1 \mathrm{~mm}^{3} \cdot \mathrm{L}^{-1}$. At the Tapajós Lake section, however, biovolume reached $6.0 \mathrm{~mm}^{3} \cdot \mathrm{L}^{-1}$, with the prevalence of cyanobacteria species, such as Synechocystis aquatilis and Aphanocapsa sp. During high water period, the Tapajos-Itaituba site showed a maximum biovolume of $0.1 \mathrm{~mm}^{3} \cdot \mathrm{L}^{-1}$, which was mostly composed of diatoms and cryptomonads. The upstream tributaries (Crepori, Jamanxim, and Novo rivers), however, presented lower biovolume $\left(<0.1 \mathrm{~mm}^{3} \cdot \mathrm{L}^{-1}\right)$ consisting of an assemblage of different taxonomic groups, including chrysophyceae, diatom, cryptomonads, and cyanobacteria.

Regarding the total pigment concentration, relatively higher magnitudes (up to $1.9 \mu \mathrm{g} \cdot \mathrm{L}^{-1}$ ) in the main Tapajós channel compared to the tributaries $\left(<0.1 \mu \mathrm{g} \cdot \mathrm{L}^{-1}\right)$ were observed. The contribution of auxiliary pigments in relation to chl-a ((pigm.)/(chl-a)) at Tapajós-Itaituba and Tapajós Lake was chl-b $(42 \%)$, zeaxanthin $(18 \%)$, and fucoxanthin $(11 \%)$, thus indicating that the majority of the phytoplankton groups were composed of cyanobacteria (zeaxanthin marker) and diatoms (fucoxanthin) [53], as is also shown in the microscopy results (Figure 4a).

During the low water level, total pigment concentration varied between 1.0 and $2.0 \mu \mathrm{g} \cdot \mathrm{L}^{-1}$ for all samples, with no clear difference in pigment contents and concentrations between the Tapajós Lake and the main channel and tributaries (e.g., Crepori River). The total pigment concentration in the Crepori River was higher during low water level period than at high water period, similar to the biovolume data. Overall, the relative contribution of auxiliary pigments remained consistent throughout the samples, showing chl-b (14\%), zeaxanthin (14\%), and fucoxanthin (4\%) as the main contributors, thus indicating the presence of chlorophyte, cyanobacteria, and diatoms, confirmed with microscopy analysis. 


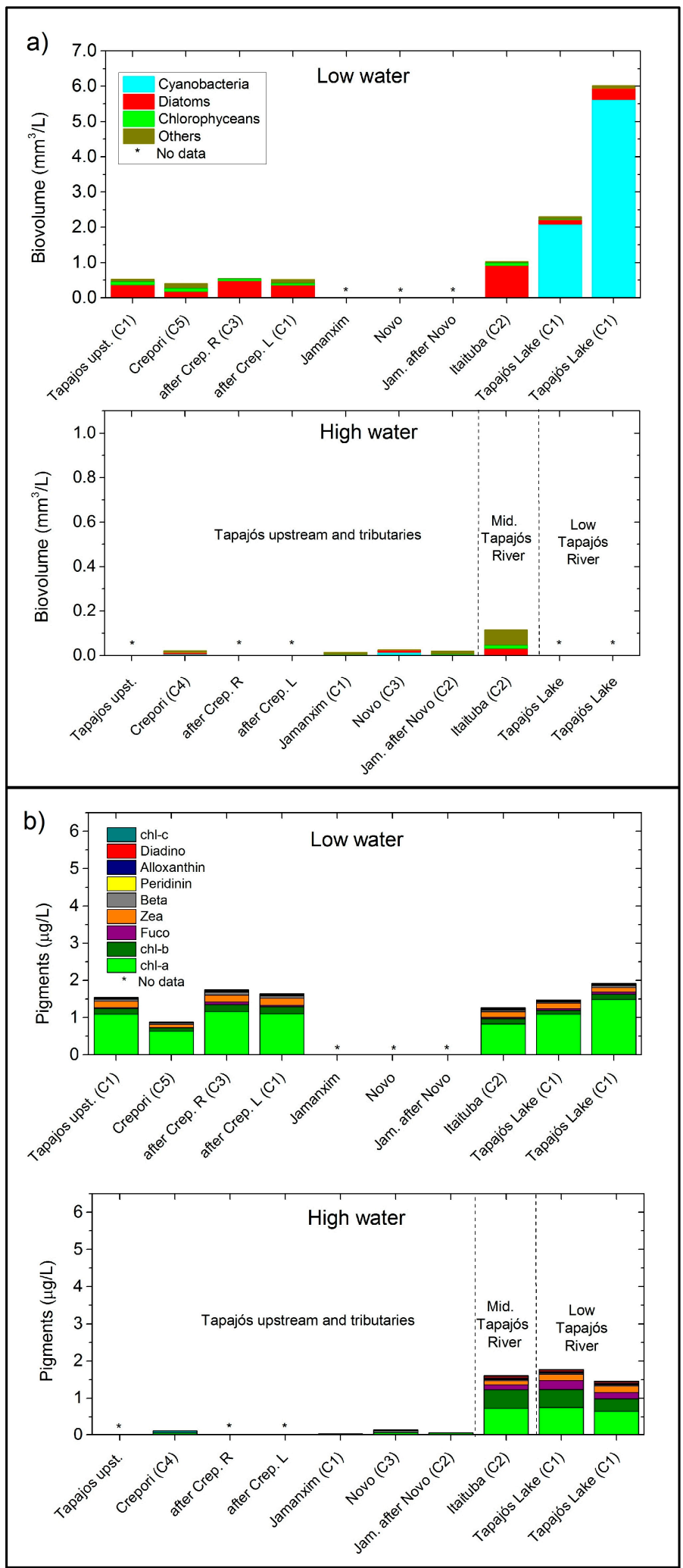

Figure 4. (a) Spatial distribution of phytoplankton groups $\left(\mathrm{mm}^{3} \cdot \mathrm{L}^{-1}\right)$ along the Tapajós River for low and high water level periods. (b) Spatial distribution of pigments concentration $\left(\mu \mathrm{g} \cdot \mathrm{L}^{-1}\right)$ for the same seasons. The correspondent TSS class is indicated in parentheses for each sample point, except for point stations with no data available, which is indicated by asterisks. 


\subsection{Bio-Optical Data}

\subsubsection{Inherent Optical Properties (IOPs)}

The absorption spectra by coloured dissolved organic matter $\left(a_{c d o m}\right)$ has a typical power-law function, decreasing from blue towards red wavelengths (Figure 5a), and similar $a_{c d o m}$ (440) magnitudes $\left(\sim 2.7 \mathrm{~m}^{-1}\right)$ among the different classes of water, except for Class 4 , which showed slightly lower $a_{\text {cdom (440) }}\left(2.0 \mathrm{~m}^{-1}\right)$ (Table 2).
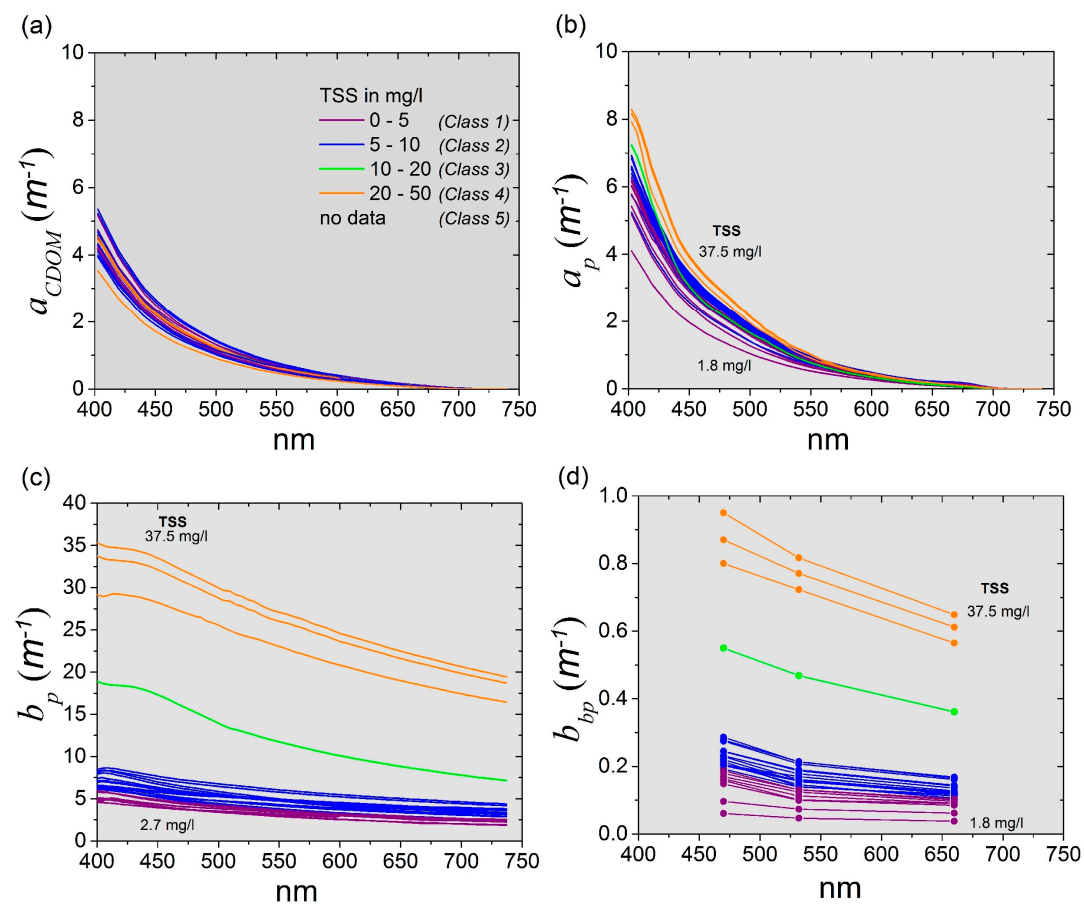

Figure 5. Spectral distribution of in situ IOPs for different water classes: absorption by particles (a) and $\operatorname{CDOM~(b);~and~particulate~scattering~(c)~and~backscattering~(d).~Gray~scale~curves~represent~the~}$ five classes of water as explained in the section above. Note that Class 5 is not shown in (b-d) due to lack of data.

Generally, $a_{p}, b_{p}$, and $b_{b p}$ showed a larger variability than $a_{c d o m}$, and similar to the TSS trend (i.e., the IOPs magnitude increased from Class 1 to Class 4). As a result, TSS was significantly correlated $(p<0.05)$ to $b_{p}$ and $b_{b p}$, with correlation coefficients as high as 0.99 for both (Table 3$)$.

Table 3. Correlation coefficients between IOPs and suspended solids, chl- $a$ and AOPs. Data are from high water only $(n=27)$. ${ }^{*}$ indicates significant correlation at $p<0.05$.

\begin{tabular}{ccccc}
\hline \multirow{2}{*}{ IOPs } & \multicolumn{2}{c}{ Suspended Solids } & Pigm. & Meas. AOP \\
\cline { 2 - 5 } & TSS & POC & chl-a & $\boldsymbol{K}_{\boldsymbol{d}(\text { PAR })}$ \\
\hline $\boldsymbol{a}_{p(440)}$ & $0.71^{*}$ & $0.80^{*}$ & 0.02 & $0.88^{*}$ \\
$\boldsymbol{b}_{p(660)}$ & $0.99^{*}$ & $0.94^{*}$ & -0.27 & $0.94^{*}$ \\
$\boldsymbol{b}_{\boldsymbol{b} p(660)}$ & $0.99^{*}$ & $0.94^{*}$ & -0.32 & $0.95^{*}$ \\
\hline
\end{tabular}

Particulate absorption, $a_{p}(440)$, magnitudes ranged from 1.4 for Class 1 to $2.9 \mathrm{~m}^{-1}$ for Class 4 (Figure $5 \mathrm{~b}$ ), and $b_{p}(660)$ from 2.7 for Class 1 to $20.8 \mathrm{~m}^{-1}$ for Class 4 (Figure $5 \mathrm{c}$ ). Further, the contribution of $b_{p}(660)$ to total attenuation varied from $34 \%$ for Class 1 to $>80 \%$ for Classes 4 and 5 (Figure $5 \mathrm{~d}$ ). The backscattering coefficient, $b_{b p}(660)$, also exhibited a similar trend, increasing from $0.10 \mathrm{~m}^{-1}$ for Class 1 to $0.60 \mathrm{~m}^{-1}$ for Class 4 (Table 2). 


\subsubsection{Apparent Optical Properties (AOPs) and Underwater Light Field}

The spectra for diffuse attenuation of downwelling irradiance $\left(K_{d}\right)$ was higher at blue wavelengths and decreased towards green and red wavelengths (Figure 6), similar to the IOPs spectra. Considering the PAR range, Class 1 presented a $K_{d}$ (PAR) of $1.9 \mathrm{~m}^{-1}$, and Class 5 values were as high as $9.6 \mathrm{~m}^{-1}$. Not surprisingly, $K_{d}$ (PAR) showed a strong linear correlation with TSS for all wavelengths, for example, at $660 \mathrm{~nm}(\mathrm{r}=0.96), 560 \mathrm{~nm}(\mathrm{r}=0.94)$, and $440 \mathrm{~nm}(\mathrm{r}=0.84, p<0.05, n=40)$. Again, similar correlations were not observed for chl-a and $a_{c d o m}$ (440) data (Table 4), thus indicating the prevalent role of inorganic suspended particulates in the AOPs.

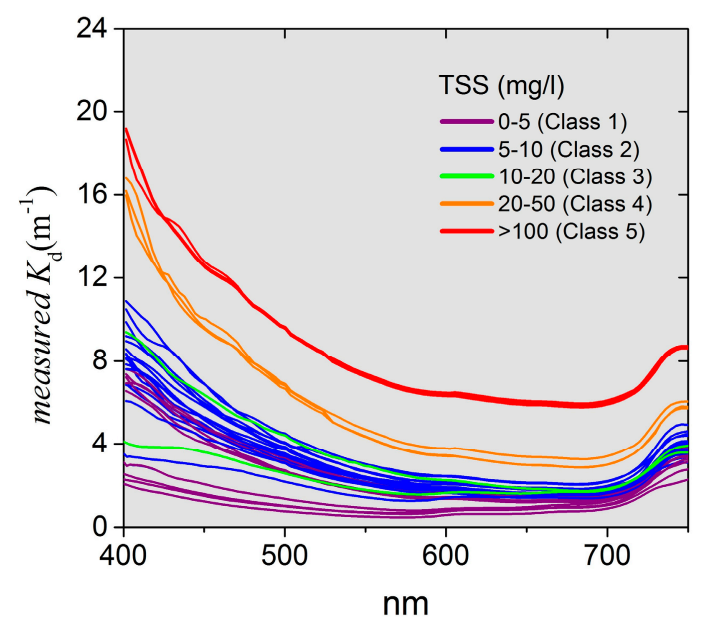

Figure 6. Diffuse attenuation coefficient $K_{d}(\lambda)$, for both field campaigns for classes under different mining impacts from low impact (Class 1 ) to very high (Class 5).

Table 4. Correlation coefficients between suspended sediment, $c h l-a$, and $a_{c d o m}$, with measured and modeled AOPs. Data are from high and low water $(n=40) .{ }^{*}$ indicates significant correlation at $p<0.05$.

\begin{tabular}{ccccc}
\hline & \multicolumn{4}{c}{ Measured AOPS } \\
\cline { 2 - 5 } & $\boldsymbol{K}_{\boldsymbol{d}(\mathbf{4 4 0 )}}$ & $\boldsymbol{K}_{\boldsymbol{d}(\mathbf{5 6 0})}$ & $\boldsymbol{K}_{\boldsymbol{d}(\mathbf{6 6 0})}$ & $\boldsymbol{K}_{\boldsymbol{d}(\mathrm{PAR})}$ \\
\hline TSS & $0.84^{*}$ & $0.94^{*}$ & $0.96^{*}$ & $0.91^{*}$ \\
POC & $0.89^{*}$ & $0.95^{*}$ & $0.97^{*}$ & $0.93^{*}$ \\
$\boldsymbol{a}_{\text {CDOM }}$ & -0.48 & -0.34 & -0.25 & -0.37 \\
chl- $\boldsymbol{a}$ & -0.20 & -0.20 & -0.21 & -0.19 \\
\hline
\end{tabular}

Overall, $\bar{E}_{O}(0.3 \mathrm{~m}, \lambda)$ showed an average magnitude around 1.0 with a spectral shape increasing from blue to red wavelengths (Figure 7a). Values higher than 1.0 can occur when the upwelling irradiance, $E_{u(0.3 \mathrm{~m}, \lambda)}$, contributes significantly to the total scalar irradiance [54]. At sub-surface, $\bar{E}_{o}$ $(0.3 \mathrm{~m}, \lambda)$ for Class 1 was about 0.5 in the blue region, and approximately 1.0 at green and red wavelengths. In more turbid waters (Classes 4 and 5), short wavelengths decreased quickly at sub-surface. Whereas, green and mainly red wavelengths showed $\bar{E}_{O(0.3 \mathrm{~m})}$ values up to 1.7 of incoming light, thus comprising most of the $\bar{E}_{O}(0.3 \mathrm{~m}, P A R)$ at this depth (Table 2). At a depth of $2.0 \mathrm{~m}$, light intensity for all classes is mostly concentrated within the green and red wavelengths; blue light is fully attenuated, even for Class 1 (Figure 7). At this depth, Class 5 presented only $0.1 \%$ of the incoming PAR light, increasing towards Class $4(0.4 \%)$, Class $3(10.1 \%)$, Class $2(13.5 \%)$, and Class $1(18.0 \%)$.

The depth in which $\bar{E}_{o \text { (PAR) }}$ is $1 \%\left(Z_{1 \%}\right)$ varied from $6.0 \mathrm{~m}$ for Class 1 to average of 5.4, 4.3, 3.6, 2.8, and $1.7 \mathrm{~m}$ for Classes 2 to 5, respectively. The wavelength in which light penetrates the most at $Z_{1 \%}$ shifted from $620 \mathrm{~nm}$ (Classes 1 and 2) to $660 \mathrm{~nm}$ in turbid waters (Classes 4 and 5) (Figure 7c). 
The critical depth, $Z_{c}$, for Chlamydomonas sp., used here is representative of the species in our samples, indicating that for water of Class 1, enough light was available for photosynthesis up to $6.0 \mathrm{~m}$ depth (Figure 7). As water turbidity increased, a decrease in $Z_{c}$ was observed (Table 2). Note that within the upper $0.5 \mathrm{~m}$, the scalar irradiance available can be higher than the $E_{\max }$, which is the maximum level of irradiance that yields photosynthesis.

a)

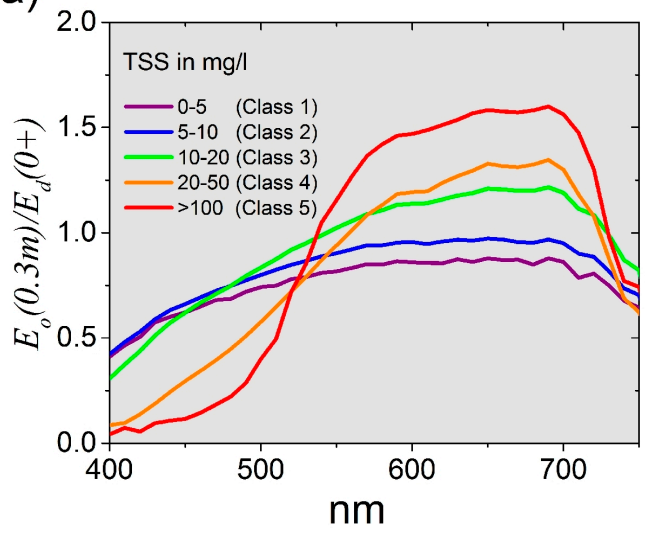

c)

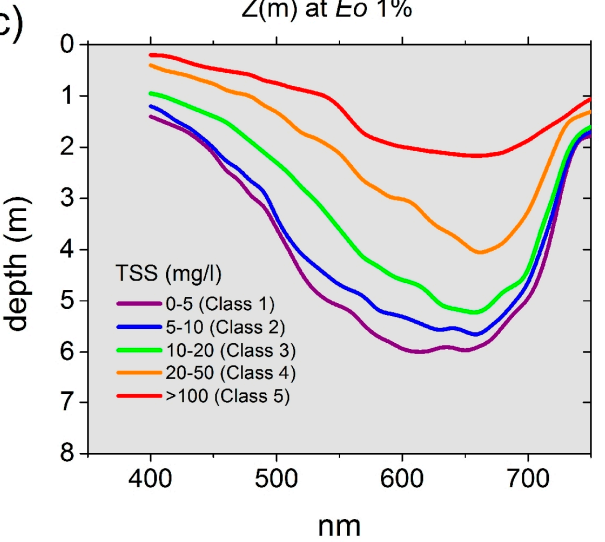

b)

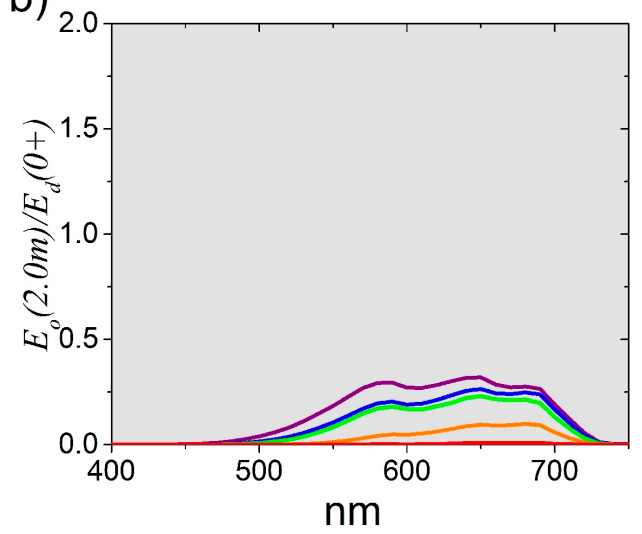

d)

$E_{o}(P A R) \mu E m^{-2} s^{-1}$

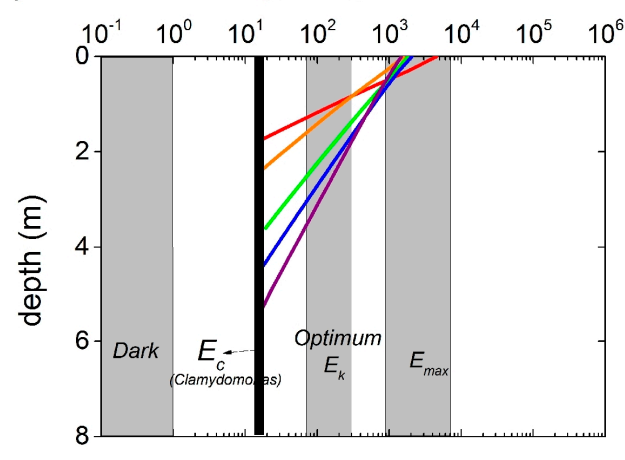

Figure 7. Normalized scalar irradiance at (a) $0.3 \mathrm{~m}$ and (b) $2.0 \mathrm{~m}$ for all samples grouped by TSS. (c) Spectral profile of $Z_{1 \%}$ averaged for each class, and (d) $E_{0}$ (PAR) availability from surface to bottom with depth. Compensation irradiance $E_{c}(\mathrm{PAR})$ for Chlamydomonas sp. is indicated (thick vertical black line). The correspondent critical depth, $Z_{c}(\mathrm{PAR})$, for each class can be drawn from the intersection of $E_{o}(\mathrm{PAR})$ with the $E_{c}(\mathrm{PAR})$ line. $E_{\max }$, is the maximum level of irradiance that yields photosynthesis. Above this point, the incident light combined with upwelling light can be harmful for phytoplankton cells. The optimum irradiance level, $E_{k}$, is between $E_{c}$ (critical) and $E_{\max }$.

\section{Discussion}

Water siltation caused by ASGM in the Tapajós River Basin over the past 40 years has been demonstrated by Lobo et al. [51,55], using a historical Landsat imagery archive. From 1978 to 1993, the introduction of low-budget mechanization associated with very high gold prices resulted in the large expansion of mining area and high water siltation levels. After a general recession during the 1990s and early 2000s, in the past 12 years, ASGM has intensified encouraged by high gold prices, resulting in expansion of mining sites and increase of TSS input to the rivers. The current gold rush in this region raises the concern about the aquatic impacts caused by the discharge of mining tailings into the rivers.

To investigate this issue, the present study provides a full characterization of the optical changes due to increased TSS from mining tailings for the Tapajós River and tributaries. Among the main 
findings, measured optical properties indicated that the incoming light (PAR) is rapidly attenuated with increased TSS concentrations caused by ASGM activity. Non-impacted tributaries presented a critical depth for phytoplankton productivity of up to $6.0 \mathrm{~m}$, while for greatly impacted waters, attenuation of light was rapid, reducing $Z_{c}$ to about $1.7 \mathrm{~m}$, with most of the available light comprising red wavelengths.

\subsection{Mining-Derived TSS as the Main Factor Changing the Water Optical Properties and Light Field}

Amongst the sampled rivers, the upstream section of the Tapajós River is naturally classified as "clearwater" $[21,24,25]$. This class presented relatively low TSS $\left(\sim 5.0 \mathrm{mg} \cdot \mathrm{L}^{-1}\right)$, low dissolved organic matter $\left(a_{c d o m}<2.5 \mathrm{~m}^{-1}\right)$, and low $c h l-a\left(<1.0 \mu \mathrm{g} \cdot \mathrm{L}^{-1}\right)$, thus resulting in a relatively deep euphotic zone $\left(Z_{1 \%} \sim 6.0 \mathrm{~m}\right)$. In these waters, the suspended sediment has a considerable amount of organic matter ( $\sim 30 \%$ of TSS), composed mostly of allochthonous plant debris [33]. The characteristics and concentration of the suspended sediments change abruptly as the Tapajós River receives clay-rich tributaries, such as the heavily-mined Crepori River (TSS $\sim 11.3 \mathrm{mg} \cdot \mathrm{L}^{-1}$, particulate organic matter $<3 \%$, and euphotic depth $\sim 2.0 \mathrm{~m}$; defined as Class 5). The sediment plume from the Crepori River only fully mixes with the Tapajós River waters at about $200 \mathrm{~km}$ downstream after passing through rapids [21,51]. After these rapids, as the water velocity decreases, the fine suspended solids sink, and concentrations decrease to values similar to those of the upstream Tapajós River (see Telmer et al. [21]). Similarly to the Tapajós River, TSS at the Jamanxim River (Class 1 and Class 2) increases as it receives a sediment-rich discharge from the Novo and the Tocantins sub-basins (Class 3 ) subject to mining operations (Figure 3).

Seasonally, from low to high water level period, the increase of TSS is, in part, a result of the sediment input carried during rain events as the water rises [24,56]. Gold mining activities are also temporally dynamic given that they intensify during the dry season [57] when access to mining pits are facilitated. This intensification combined with the lower river levels during that season, increases sediment concentrations to above $100 \mathrm{mg} \cdot \mathrm{L}^{-1}$ at Crepori River (Figure 3), the most ASGM-impacted basin. Recent results of an ongoing research [58] assessing the proportion sediment production from diffused soil erosion to that of ASGM showed that, approximately, $10 \%$ of sediment concentration measured at Crepori River (above $100 \mathrm{mg} \cdot \mathrm{L}^{-1}$ ) could be attributed to diffuse soil erosion throughout the year. Therefore, the remaining $90 \%$ of the TSS concentration observed can be attributed to mining tailings.

In the Tapajós region, the mining tailings flushed into the rivers are composed of an agglomeration of fine clay particles [21,59], mostly kaolinite [23]. Specifically, the fine inorganic clay particles are more effective at scattering and backscattering light due to their higher refractive index compared to large inorganic particulates (silt, medium sand), organic particulates such as flocs (agglomeration of particles), and phytoplankton [60-62]. These mine-derived clay particles play a strong role in the magnitude and spectral dependency of IOPs and AOPs compared with waters under less or no influence of mined rivers (see correlations on Tables 3 and 4).

The absorption curves for particulate matter showed typical power-law function [42]; the typical chl- $a$ absorption peak at $675 \mathrm{~nm}$, however, was not clearly observed, indicating that suspended matter, mostly of inorganic nature, and dissolved organic matter are the main optical components absorbing light in the non-impacted (Class 1) and impacted tributaries (Classes 3-5), respectively.

Measured $b_{660}$ magnitudes increased one order of magnitude from Class $1\left(2.1 \mathrm{~m}^{-1}\right)$ to Class 4 $\left(20.8 \mathrm{~m}^{-1}\right)$, and are comparable with other scattering coefficients reported for turbid inland waters. For example, Sun et al. [63] reported $b_{660}$ acquired in Taihu Lake, a turbid lake in China, up to $22.0 \mathrm{~m}^{-1}$ with increasing inorganic concentration (around $33.0 \mathrm{mg} \cdot \mathrm{L}^{-1}$, which corresponds to Class 4 in our study, for which $b_{660}$ is on average $\left.20.8 \mathrm{~m}^{-1}\right)$. Similarly to scattering, $b_{b 660}$ showed high values $\left(0.65 \mathrm{~m}^{-1}\right.$ for Class 3, for example), which are comparable to the average backscattering $\left(b_{b 700}\right)$ of $0.80 \mathrm{~m}^{-1}$ reported for waters where TSS reached $18.9 \mathrm{mg} \cdot \mathrm{L}^{-1}$ in the Curuai Lake, adjacent to the Tapajós 'Lake' [64]. 
Both scattering and backscattering coefficients are primarily controlled by mineral concentration (TSS) as reported by several authors $[45,63,65-68]$. Increasing TSS concentration yielded positive and significant $(p<0.05)$ correlation with $b_{p}(660), b_{b p}(660)$, and $a_{p}(440)$. Correlations of optical properties with chl-a and $a_{c d o m}$ (440) were not as significant (see correlations on Tables 3 and 4), what is explained by the inorganic nature of the soils subject to mining in the Tapajos watershed $[7,23]$.

The IOP of waters with high concentrations of fine sediment results in changes in the $K_{d}$ and consequently in the underwater light field. This is represented by the defined five water classes representing increasing TSS (Figure 7). Measured $K_{d(P A R)}$ values varied from $2.0 \mathrm{~m}^{-1}$ for Class 1 to $9.6 \mathrm{~m}^{-1}$ for Class 5 (Table 2), which is similar to results reported for other mine-impacted areas in New Zealand, where $K_{d(P A R)}$ varied on average from 1.6 to $8.4 \mathrm{~m}^{-1}$ as averaged TSS increased from 1.2 to $>100.0 \mathrm{mg} \cdot \mathrm{L}^{-1}$ [69]. Other studies, specifically in the mine tailings of the Batata Lake, located in the Trombetas River watershed, showed that re-suspended inorganic particles derived from mining increased $K_{d}(P A R)$ by $35 \%$ when compared to non-impacted sections of the lake [16,17]. Spectrally, the attenuation coefficient showed a similar trend; $K_{d}(440), K_{d}(560), K_{d}(660)$, varying from 2.0, 1.5, 1.2, and 1.0 (Class 1) to 13.1, 8.0, and $7.0 \mathrm{~m}^{-1}$ (Class 5), respectively. These $K_{d}$ (440) magnitudes are comparable to values reported by Costa et al. [32] for different waters in the Amazon Basin $\left(K_{d}(440)\right.$ up to $3.0 \mathrm{~m}^{-1}$ in clear and $15.1 \mathrm{~m}^{-1}$ in turbid waters). The authors also reported $K_{d}(660)$ values lower than those of the blue spectra, but still higher in white waters $\left(9.5 \mathrm{~m}^{-1}\right.$, corresponding to Class 5) in comparison to clear waters (up to $1.7 \mathrm{~m}^{-1}$, corresponding to Class 1 ).

The distinct spectral attenuation of the incoming light is a function of the variation in the scattering and absorption processes within the PAR range $(400-700 \mathrm{~nm})$. For tributaries with low or no influence of mining tailings, waters are relatively more absorbent with $b: a$ ratio of 0.8 at the blue range, and increasing towards the red range ( $b: a$ of 20.0 at $660 \mathrm{~nm})$. The relative low scattering properties of these waters result in lower spectral $K_{d}$ and, consequently, a more homogeneous spectral light field with a significant amount of light at the green spectra (Figure 7a). On the other hand, with an increase in TSS loadings from mining operations, the scattering coefficient increases. In this case, the scattering process prevails over absorption coefficient, specifically at the green and red wavelengths, thus explaining the observed higher underwater light availability at the green and, mainly, at the red wavelengths (Figure 7). This is particularly the case when analyzing $E_{o}$ since both the upwelling and downwelling light fields are considered in the calculations. In turbid waters where the $b: a$ in the blue spectra is approximately 30.0, such as the case for Class $4, E_{o}(0.3 \mathrm{~m})$ values became $50 \%$ higher than $E_{d\left(0^{+}\right)}$(Figure 7). Overall, considering the scalar irradiance $\left(E_{o}\right)$ for assessment of light availability is particularly important for highly turbid waters where increased $E_{u}$ contributes significantly to scalar irradiance $\left(E_{0}\right)$ available for suspended phytoplankton.

\subsection{Underwater Light Field and Phytoplankton}

As an initial attempt to evaluate the consequences of reduced light to the phytoplankton biovolume, $Z_{c}$ was calculated for the studied waters considering the light requirements, $E_{\mathcal{c}}$ (PAR), for Chlamydomonas sp. (Chlorophyta) [47]. However, $Z_{c}$ alone does not explain PAR availability for phytoplankton growth. A second parameter is needed for this analysis, which is the depth of the mixing layer $\left(Z_{m}\right)$. In a river system, $Z_{m}$ depends on water mixing originated from bottom interaction (friction) and water flow [70,71]. For the studied rivers, a deep mixing layer was considered due to the reported high turbulence and water flow. On average, water velocity varies from $1.09 \mathrm{~ms}^{-1}$ during the high water level period to $0.55 \mathrm{~ms}^{-1}$ during the low water level period for several studied tributaries, such as the Crepori, Jamanxim, and Tocantins rivers [72]. For reference, water velocities over $0.5 \mathrm{~ms}^{-1}$ are considered the threshold velocity for phytoplankton growth as indicated by Salmaso et al. [73]. Therefore, in both seasons, those rivers are likely to have their phytoplankton production limited by turbulent flux.

Given the high turbulence, this study assumes that the mixing layer, $Z_{m}$, is equivalent to the total water depth $(Z)$ to calculate $Z_{m} / Z_{c}$. For non-impacted tributaries, such as the upstream Tapajós and the 
Jamanxim rivers (Class 1), the $Z_{m} / Z_{c}$ is lower than 1.3, indicating that there is enough light available in approximately $75 \%$ of the water column. On the other hand, impacted rivers, such as the Crepori (Class 4) and the Tocantins (Class 3), showed $Z_{m} / Z_{c}$ of $\sim 2.0$ during the high water level period, which suggests a reduction of light availability to half of the water column. Analogous restriction of light availability has been reported in the Amazon River and it is associated with the low chl-a concentration given that nutrients are not limited in these waters [24,32,50,56].

Although the phytoplankton data available for this study is limited, the results show low values of phytoplankton biovolume and chl- $a$ (Figure 4) for both impacted (Crepori, Tocantinzinho, and Novo rivers) and non-impacted rivers (Tapajos upstream, Jamanxin upstream rivers), except the Tapajós lake region. For the impacted and non-impacted rivers, our findings suggest that the increase in PAR attenuation due to increase in water siltation does not necessarily cause a direct reduction in light availability for phytoplankton growth. Here, we are suggesting that a combination of light availability and river turbulence, as described by $Z_{m} / Z_{c}$, control phytoplankton growth, assuming these rivers are not nutrient limited. Interestingly, seasonal factors may play a more important role in biovolume and pigment concentration than the degree of mining. For instance, phytoplankton biovolume data and chl-a for both groups of rivers (impacted and non-impacted) are higher during the low water level period, which is possibly related to other factors such as seasonal irradiance levels, nutrient availability, and water flow velocity [34]. In the Amazon region, the seasonal irradiance regime shows relatively lower values during the high water period (rainy season) $\left(\sim 950 \mathrm{~mol} \cdot \mathrm{m}^{-2} \cdot \mathrm{mo}^{-1}\right)$ then during the low water period $\left(\sim 1300 \mathrm{~mol} \cdot \mathrm{m}^{-2} \cdot \mathrm{mo}^{-1}\right)$ [74]. The higher irradiance during the low water period further explains the observed higher phytoplankton production in some of the Amazonian rivers [75]. On the other hand, our data showed that during the rainy season, phytoplankton biovolume and chl-a decreased, most likely because of monthly PAR irradiance reduction [74,75]. In fact, according to INMET (inmet.gov.br) data, the number of sunny hours for the period of our data collection varied from 231 during the low water level period to 126 sunny days during high water level; that is, 1.83 times higher during the low water period.

\section{Conclusions}

The ASGM expansion over the past 40 years in the study area $[51,55]$ has directly impacted the investigated rivers with high sediment content and mercury contamination [21]. To complement these previous studies, the present article investigated the effects of water siltation on the underwater light field of various tributaries within the Tapajós River Basin. The effects of TSS derived from mining activities on both the inherent and apparent optical properties were quantified. The main conclusions are as follows.

The inorganic nature of mine tailings is the main factor affecting the underwater scalar irradiance in the Tapajós River Basin. The TSS concentration varies seasonally during the year in a synergism between water level and mining activities: during low water level periods, mining activities intensify and, associated with low water volume, TSS rapidly increases, which in turn changes the optical characteristics of the water. For tributaries with low or no influence of mine tailings, waters are relatively more absorbent. On the other hand, with TSS loadings from mining operations, the scattering process prevails over the absorption coefficient at the green and red wavelengths, thus explaining why we observed higher underwater light availability at the red wavelengths in highly turbid waters. Moreover, ASGM not only affects the sediment load but also its natural seasonality since in non-impacted basins the maximum TSS is caused by diffuse erosion during the rainy season. This change in load and seasonality might affect, in the long run, biota composition of a previous clear water environment to a distinct light availability regime as the river becomes subjected to mining operations.

Although a strong light reduction due to water siltation was observed in impacted tributaries, the effects on the phytoplankton community was not clearly observed, which can be attributed to a combination of (i) minimal number of samples for proper comparison between impacted and non-impacted tributaries, and (ii) general low phytoplankton productivity in all upstream tributaries 
due to a combination of high current velocity (flushing) in rivers and light conditions. Therefore, due to the lack of comparable (impacted vs. non-impacted) data on phytoplankton species and concentration, the question of whether the reduction of light negatively affects phytoplankton growth requires further investigation.

In previous publications $[51,55]$, we provided historical maps with TSS retrieved from satellite images indicating that the optical description provided in this article is directly related to remote sensing signal, and can be extended to several rivers that are subject to similar mining impacts. In fact, using remote sensing techniques, ongoing research indicates that other clear and black water rivers such as Xingu River and Amanã River, respectively, are also presenting effects of mine tailings on the aquatic environment. As such, information derived from this research and other ongoing initiatives will support control actions by IBAMA (Brazilian Environmental Protection Agency) and ICMBio (Brazilian Agency of Protected Areas) towards illegal mining activities along streams and within protected areas in the Amazon. Further, the hydrological approach by Abe et al. [58] will aid in understanding the sources of suspended sediment by quantifying the natural runoff sediment production and comparing it to the sediment concentration observed in the present article.

Acknowledgments: This research was developed in a partnership between the University of Victoria (UVic), the Brazilian Institute for Space Research (INPE), and the Artisanal Gold Council. The authors would like to acknowledge logistical support by ICMBio represented by Haroldo Marques. We also acknowledge financial support from the National Sciences and Engineering Research Council of Canada (NSERC) to Costa, from FAPESP (Process 2011/23594-8) to Novo, and CNPq (237930/2012-9 and 150835/2015-9) to the lead author. We are thankful to Diane Braithwaite for English revisions.

Author Contributions: This research is part of Felipe de Lucia Lobo's Ph.D. thesis. He participated in every step of this article from planning, data collection, analysis, and writing the manuscript as the first author. Maycira Costa was the main supervisor of this research and had active participation in planning, data analysis, and text editing. Evlyn Márcia Leão de Moraes Novo was the co-supervisor of this research and was fundamental to define the research approach and data analysis. Kevin Telmer is the Executive Director of the Artisanal Gold Council and provided key information for data analysis and discussion of the results.

Conflicts of Interest: The authors declare no conflict of interest.

\section{Appendix A}

The biogeochemical data was separated into five preliminary classes according to the concentration of total suspended solids (TSS) aiming to facilitate the interpretation of the results. The definition of classes was based on prior knowledge of the level of mining impact on the sampled rivers and statistical tests for significant differences on TSS (non-parametric Mann-Whitney U Tests; $\mathrm{p}<0.10)$. The non-parametric test confirmed the significant TSS difference among the five classes previously defined.

Table A1. Mann-Whitney U Test for TSS concentration Marked tests are significant at $p<0.10$.

\begin{tabular}{|c|c|c|c|c|c|c|c|}
\hline & Valid N & Valid N & Rank Sum & Rank Sum & $\mathbf{U}$ & $\mathrm{Z}$ & $p$-Value \\
\hline \multirow[t]{2}{*}{ Class 1 vs. Class 2} & class 1 & class 2 & class 1 & class 2 & & & \\
\hline & 16 & 17 & 136.00 & 425.00 & 0.00 & -4.881 & 0.000 \\
\hline \multirow[t]{2}{*}{ Class 2 vs. Class 3} & class 2 & class 3 & class 2 & class 3 & & & \\
\hline & 17 & 2 & 153.00 & 37.00 & 0.00 & -2.192 & 0.028 \\
\hline \multirow{2}{*}{ Class 3 vs. Class 4} & class 3 & class 4 & class 3 & class 4 & & & \\
\hline & 2 & 3 & 3.00 & 12.00 & 0.00 & -1.443 & 0.096 \\
\hline \multirow[t]{2}{*}{ Class 4 vs. Class 5} & class 4 & class 5 & class 4 & class 5 & & & \\
\hline & 3 & 3 & 6.00 & 15.00 & 0.00 & -1.746 & 0.081 \\
\hline
\end{tabular}




\section{References}

1. Seccatore, J. An estimation of the artisanal small-scale production of gold in the world. Sci. Total Environ. 2014, 496, 662-667. [CrossRef] [PubMed]

2. Telmer, K.; Veiga, M. World emissions of mercury from artisanal and small scale gold mining. In Mercury Fate and Transport in the Global Atmosphere: Emissions, Measurements and Models; Springer: Boston, MA, USA, 2009; Chapter 6; pp. 131-172. ISBN 978-0-387-93958-2.

3. Grätz, T. Moralities, risk and rules in West African artisanal gold mining communities: A case study of northern Benin. Resour. Policy 2009, 34, 12-17. [CrossRef]

4. Coelho, M.C.N.; Wanderley, L.J.; Costa, R.C. Small scale gold mining in the XXI century. Examples in the south-west Brazilian Amazon. Anu. Inst. Geociênc. UFRJ 2016, 39, 10.

5. Nevado, J.J.B.; Martin-Doimeadios, R.C.R.; Bernardo, F.J.G.; Moreno, M.J.; Herculano, A.M.; do Nascimento, J.L.M.; Crespo-Lopez, M.E. Mercury in the Tapajos River Basin, Brazilian Amazon: A review. Environ. Int. 2010, 36, 593-608. [CrossRef] [PubMed]

6. Dorea, J.G.; Barbosa, A.C. Anthropogenic impact of mercury accumulation in fish from the Rio Madeira and Rio Negro rivers (Amazonia). Biol. Trace Elem. Res. 2007, 115, 243-254. [CrossRef] [PubMed]

7. Rodrigues, R.M.; Mascarenhas, A.F.S.; Ichihara, A.H.; Souza, T.M.C. Estudo dos Impactos Ambientais Decorrentes do Extrativismo Mineral e Poluição Mercurial no Tapajós_Pré-Diagnóstico; CETEM/CNPq: Rio de Janeiro, Brazil, 1994; p. 220.

8. Dambacher, J.M.; Brewer, D.T.; Dennis, D.M.; Macintyre, M.; Foale, S. Qualitative modelling of gold mine impacts on Lihir island's socioeconomic system and reef-edge fish community. Environ. Sci. Technol. 2007, 41, 555-562. [CrossRef] [PubMed]

9. Schueler, V.; Kuemmerle, T.; Schroeder, H. Impacts of surface gold mining on land use systems in western Ghana. Ambio 2011, 40, 528-539. [CrossRef] [PubMed]

10. Tudesque, L.; Grenouillet, G.; Gevrey, M.; Khazraie, K.; Brosse, S. Influence of small-scale gold mining on French Guiana streams: Are diatom assemblages valid disturbance sensors? Ecol. Indic. 2012, 14, 100-106. [CrossRef]

11. Finer, M.; Novoa, S. Gold Mining Deforestation Continues to Expand in la Pampa (Madre De Dios, Peru). Available online: http:/ / maaproject.org/2015/03/gold-mining-deforestation-expand-peruvian-amazon/ (accessed on 26 January 2016).

12. Mol, J.H.; Ouboter, P.E. Downstream effects of erosion from small-scale gold mining on the instream habitat and fish community of a small neotropical rainforest stream. Conserv. Biol. 2004, 18, 201-214. [CrossRef]

13. Sousa, R.N.; Veiga, M.M. Using performance indicators to evaluate an environmental education program in artisanal gold mining communities in the Brazilian Amazon. Ambio 2009, 38, 40-46. [CrossRef] [PubMed]

14. Couceiro, S.R.M.; Hamada, N.; Forsberg, B.R.; Padovesi-Fonseca, C. Trophic structure of macroinvertebrates in amazonian streams impacted by anthropogenic siltation. Austral Ecol. 2011, 36, 628-637. [CrossRef]

15. Boudou, A.; Maury-Brachet, R.; Coquery, M.; Durrieu, G.; Cossa, D. Synergic effect of gold mining and damming on mercury contamination in fish. Environ. Sci. Technol. 2005, 39, 2448-2454. [CrossRef] [PubMed]

16. Roland, F.; Esteves, F.D. Effects of bauxite tailing on par attenuation in an Amazonian crystalline water lake. Hydrobiologia 1998, 377, 1-7. [CrossRef]

17. Guenther, M.; Bozelli, R. Effects of inorganic turbidity on the phytoplankton of an Amazonian lake impacted by bauxite tailings. Hydrobiologia 2004, 511, 151-159. [CrossRef]

18. Kirk, J.T.O. Light and Photosynthesis in Aquatic Ecosystems, 3rd ed.; Cambridge University Press: Cambridge, UK; New York, NY, USA, 2011; ISBN 9780521151757.

19. Markager, S.; Vincent, W.F. Light absorption by phytoplankton: Development of a matching parameter for algal photosynthesis under different spectral regimes. J. Plankton Res. 2001, 23, 1373-1384. [CrossRef]

20. Araújo Neto, H. Perfil do Ouro; Ministério de Minas e Energia: Brasília, Brazil, 2009; p. 50.

21. Telmer, K.; Costa, M.; Simões Angélica, R.; Araujo, E.S.; Maurice, Y. The source and fate of sediment and mercury in the Tapajós River, Pará, Brazilian Amazon: Ground- and space-based evidence. J. Environ. Manag. 2006, 81, 101-113. [CrossRef] [PubMed]

22. INPE. Prodes Project. Available online: www.obt.inpe.br/prodes (accessed on 1 June 2011).

23. CPRM. Província Mineral do Tapajós: Geologia, Metalogenia e Mapa Previsional Para Ouro em SIG. 2009. Available online: http:/ / www.cprm.gov.br (accessed on 1 April 2013). 
24. Junk, W. General aspects of floodplain ecology with special reference to Amazonian floodplains. In The Central Amazon Floodplain; Junk, W., Ed.; Springer: Berlin, Germany, 1997; Volume 126, pp. 3-20.

25. Sioli, H. The amazon and its main affluents: Hydrography, morphology of the river courses, and river types. In The Amazon; Sioli, H., Ed.; Springer: Dordrecht, The Netherlands, 1984; Volume 56, pp. 127-165.

26. Rudorff, C.M.; Galvao, L.S.; Novo, E.M.L.M. Reflectance of floodplain waterbodies using EO-1 Hyperion data from high and receding flood periods of the Amazon River. Int. J. Remote Sens. 2009, 30, 2713-2720. [CrossRef]

27. Novo, E.; Barbosa, C.C.D.; de Freitas, R.M.; Shimabukuro, Y.E.; Melack, J.M.; Pereira, W. Seasonal changes in chlorophyll distributions in amazon floodplain lakes derived from MODIS images. Limnology 2006, 7, 153-161. [CrossRef]

28. Sá, L.L.C.D.; Vieira, J.M.D.S.; Mendes, R.D.A.; Pinheiro, S.C.C.; Vale, E.R.; Alves, F.A.D.S.; Jesus, I.M.D.; Santos, E.C.D.O.; Costa, V.B.D. Ocorrência de uma floração de cianobactérias tóxicas na margem direita do rio Tapajós, no município de Santarém (Pará, Brasil). Rev. Pan-Amazôn. Saúde 2010, 1, 159-166. [CrossRef]

29. Roulet, M.; Lucotte, M.; Canuel, R.; Farella, N.; Goch, Y.G.D.; Peleja, J.R.P.; Guimaraes, J.R.D.; Mergler, D.; Amorim, M. Spatio-temporal geochemistry of mercury in waters of the Tapajos and Amazon rivers, Brazil. Limnol. Oceanogr. 2001, 46, 1141-1157. [CrossRef]

30. Farella, N.; Lucotte, M.; Louchouarn, P.; Roulet, M. Deforestation modifying terrestrial organic transport in the rio Tapajós, Brazilian Amazon. Organ. Geochem. 2001, 32, 1443-1458. [CrossRef]

31. Gibbs, R.J. Amazon river: Environmental factors that control its dissolved and suspended load. Science 1967, 156, 1734-1737. [CrossRef] [PubMed]

32. Costa, M.P.F.; Novo, E.M.L.M.; Telmer, K.H. Spatial and temporal variability of light attenuation in large rivers of the Amazon. Hydrobiologia 2013, 702, 171-190. [CrossRef]

33. Roulet, M.; Lucotte, M.; Canuel, R.; Rheault, I.; Tran, S.; Gog, Y.G.D.; Farella, N.; do Vale, R.S.; Passos, C.J.S.; da Silva, E.D.; et al. Distribution and partition of total mercury in waters of the Tapajos River Basin, Brazilian Amazon. Sci. Total Environ. 1998, 213, 203-211. [CrossRef]

34. Reynolds, C.S. The Ecology of Phytoplankton; Cambridge University Press: Cambridge, UK; New York, NY, USA, 2006; ISBN 9780521844130.

35. Bernardes, M.C.; Martinelli, L.A.; Krusche, A.V.; Gudeman, J.; Moreira, M.; Victoria, R.L.; Ometto, J.; Ballester, M.V.R.; Aufdenkampe, A.K.; Richey, J.E.; et al. Riverine organic matter composition as a function of land use changes, southwest amazon. Ecol. Appl. 2004, 14, S263-S279. [CrossRef]

36. APHA. Standard Methods for the Examination of Water and Wastewater; APHA-AWWA-WEF: Washington, DC, USA, 2005; ISBN 08755304789780875530475.

37. Hansell, D.A. Biogeochemistry of total organic carbon and nitrogen in the Sargasso Sea: Control by convective overturn. Deep-Sea Res. Part II Top. Stud. Oceanogr. 2001, 48, 1649-1667. [CrossRef]

38. Buchaca, T. A comparison of HPLC pigment analyses and biovolume estimates of phytoplankton groups in an oligotrophic lake. J. Plankton Res. 2004, 27, 91-101. [CrossRef]

39. Utermöhl, H. Zur vervollkommung der quantitative phytoplankton-Methodik. Mitt. Int. Ver. Theor. Angew. Limnol. 1958, 9, 1-38.

40. Lund, J.; Kipling, C.; LeCren, E. The inverted microscope method of estimating algal number and the statistical basis of estimation by count. Hydrobiologia 1958, 11, 143-170. [CrossRef]

41. Hillebrand, H.; Dürselen, C.; Kirschtel, D.; Pollingher, U.; Zohary, T. Biovolume calculation for pelagic and benthic algae. J. Phycol. 1999, 35, 403-424. [CrossRef]

42. Mobley, C.D. Light and Water: Radiative Transfer in Natural Waters; Academic Press: Cambridge, MA, USA, 1994; ISBN 0125027508.

43. Wet Labs, I. Spectral Absorption and Attenuation Sensor (ac-s) User's Guide; WET Labs, Inc.: Philomath, OR, USA, 2013; p. 33.

44. Tilstone, G.H.; Peters, S.W.M.; van der Woerd, H.J.; Eleveld, M.A.; Ruddick, K.; Schönfeld, W.; Krasemann, H.; Martinez-Vicente, V.; Blondeau-Patissier, D.; Röttgers, R.; et al. Variability in specific-absorption properties and their use in a semi-analytical ocean colour algorithm for meris in North sea and western English channel coastal waters. Remote Sens. Environ. 2012, 118, 320-338. [CrossRef]

45. Boss, E.; Pegau, W.S. Relationship of light scattering at an angle in the backward direction to the backscattering coefficient. Appl. Opt. 2001, 40, 5503-5507. [CrossRef] [PubMed]

46. Satlantic. Prosoft 7.7 User Manual; Satlantic Inc.: Halifax, NS, Canada, 2011. 
47. Deblois, C.P.; Marchand, A.; Juneau, P. Comparison of photoacclimation in twelve freshwater photoautotrophs (chlorophyte, bacillaryophyte, cryptophyte and cyanophyte) isolated from a natural community. PLoS ONE 2013, 8, e57139. [CrossRef] [PubMed]

48. Sverdrup, H. On conditions for the vernal blooming of phytoplankton. J. Conseil 1953, 18, 287-295. [CrossRef]

49. Siegel, D.A.; Doney, S.C.; Yoder, J.A. The North Atlantic spring phytoplankton bloom and Sverdrup's critical depth hypothesis. Science 2002, 296, 730-733. [CrossRef] [PubMed]

50. Dustan, P. Terrestrial limitation of Amazon River productivity: Why the Amazon river is not green. Evol. Ecol. Res. 2009, 11, 421.

51. Lobo, F.L.; Costa, M.P.F.; Novo, E.M. Time-series analysis of Landsat-MSS/TM/OLI images over Amazonian waters impacted by gold mining activities. Remote Sens. Environ. 2015, 157, 170-184. [CrossRef]

52. Junk, W.J.; Piedade, M.T.F.; Schöngart, J.; Cohn-Haft, M.; Adeney, J.M.; Wittmann, F. A classification of major naturally-occurring Amazonian lowland wetlands. Wetlands 2011, 31, 623-640. [CrossRef]

53. Mackey, M.D.; Mackey, D.J.; Higgins, H.W.; Wright, S.W. Chemtax-A program for estimating class abundances from chemical markers: Application to HPLC measurements of phytoplankton. Mar. Ecol. Prog. Ser. 1996, 144, 265-283. [CrossRef]

54. Kuhl, M. Light penetration and light-intensity in sandy marine-sediments measured with irradiance and scalar irradiance fiberoptic microprobes rid a-1977-2009. Mar. Ecol. Prog. Ser. 1994, 105, 139. [CrossRef]

55. Lobo, F.; Costa, M.; Novo, E.; Telmer, K. Distribution of artisanal and small-scale gold mining in the Tapajós River Basin (Brazilian Amazon) over the past 40 years and relationship with water siltation. Remote Sens. 2016, 8, 22. [CrossRef]

56. Melack, J.; Forsberg, B. Biogeochemistry of Amazon floodplain lakes and associated wetlands. In The Biogeochemistry of the Amazon Basin and Its Role in a Changing World; Oxford University Press: Oxford, UK, 2001; pp. 235-276.

57. Bezerra, O.; Veríssimo, A.; Uhl, C. Impactos da Garimpagem de Ouro na Amazônia Oriental; Amazon: Belém, Brazil, 1998; p. 25.

58. Abe, C.; Novo, E.; Lobo, F.; Costa, M.P.F.; Dibike, Y. Impact of land use change on the hydrology and sediment load in an Amazonian Basin using SWAT. In Water Resources Management (In Review); Springer: Berlin, Germany, 2013.

59. Veiga, M.M. Mercury in Artisanal Gold Mining in Latin America: Facts, Fantasies, and Solutions. In Proceedings of the UNIDO_Expert Group Meeting_-Introducing New Technologies for Abatement of Global Mercury Pollution Deriving from Artisanal Gold Mining, Vienna, Auatria, 1-3 July 1997.

60. Bowers, D.G.; Binding, C.E. The optical properties of mineral suspended particles: A review and synthesis. Estuar. Coast. Shelf Sci. 2006, 67, 219-230. [CrossRef]

61. Binding, C.E.; Bowers, D.G.; Mitchelson-Jacob, E.G. Estimating suspended sediment concentrations from ocean colour measurements in moderately turbid waters; the impact of variable particle scattering properties. Remote Sens. Environ. 2005, 94, 373-383. [CrossRef]

62. Slade, W.H.; Boss, E. Spectral attenuation and backscattering as indicators of average particle size. Appl. Opt. 2015, 54, 7264-7277. [CrossRef] [PubMed]

63. Sun, D.; Li, Y.; Wang, Q.; Gao, J.; Lv, H.; Le, C.; Huang, C. Light scattering properties and their relation to the biogeochemical composition of turbid productive waters: A case study of Lake Taihu. Appl. Opt. 2009, 48, 1979-1989. [CrossRef] [PubMed]

64. Carvalho, L.A.S.D.; Barbosa, C.C.F.; Novo, E.M.L.D.M.; Rudorff, C.D.M. Implications of scatter corrections for absorption measurements on optical closure of Amazon floodplain lakes using the spectral absorption and attenuation meter (ac-S-Wetlabs). Remote Sens. Environ. 2015, 157, 123-137. [CrossRef]

65. Stramski, D.; Boss, E.; Bogucki, D.; Voss, K.J. The role of seawater constituents in light backscattering in the ocean. Prog. Oceanogr. 2004, 61, 27-56. [CrossRef]

66. Bergmann, T. Impacts of a recurrent resuspension event and variable phytoplankton community composition on remote sensing reflectance. J. Geophys. Res. 2004, 109. [CrossRef]

67. Doxaran, D.; Ehn, J.; Bélanger, S.; Matsuoka, A.; Hooker, S.; Babin, M. Optical characterisation of suspended particles in the Mackenzie River plume (Canadian Arctic ocean) and implications for ocean colour remote sensing. Biogeosciences 2012, 9, 3213-3229. [CrossRef]

68. Lorthiois, T.; Doxaran, D.; Chami, M. Daily and seasonal dynamics of suspended particles in the Rhône River plume based on remote sensing and field optical measurements. Geo-Mar. Lett. 2012, 32, 89-101. [CrossRef] 
69. Davies-Colley, R.; Hickey, C.; Quinn, J.; Ryan, P. Effects of clay discharges on streams. Hydrobiologia 1992, 248, 215-234. [CrossRef]

70. Robert, A. River Processes: An Introduction to Fluvial Dynamics; Routledge: Abingdon, UK, 2014; ISBN 1444118927.

71. Okogwu, O.I.; Ugwumba, A.O. Seasonal dynamics of phytoplankton in two tropical rivers of varying size and human impact in southeast Nigeria. Rev. Biol. Trop. 2013, 61, 1827-1840. [PubMed]

72. ANA. Hidroweb: Sistemas de Informações Hidrológicas. Available online: http://hidroweb.ana.gov.br/ HidroWeb (accessed on 1 May 2013).

73. Salmaso, N.; Zignin, A. At the extreme of physical gradients: Phytoplankton in highly flushed, large rivers. Hydrobiologia 2010, 639, 21-36. [CrossRef]

74. Brando, P.M.; Goetz, S.J.; Baccini, A.; Nepstad, D.C.; Beck, P.S.A.; Christman, M.C.; DeFries, R.S. Seasonal and interannual variability of climate and vegetation indices across the Amazon. Proc. Natl. Acad. Sci. USA 2010, 107, 14685-14690. [CrossRef] [PubMed]

75. Casali, S.; Calijuri, M.D.C.; Barbarisi, B.; Renó, V.F.; Affonso, A.G.; Barbosa, C.; Silva, T.S.F.; Novo, E.M.L.D.M. Impact of the 2009 extreme water level variation on phytoplankton community structure in lower Amazon floodplain lakes. Acta Limnol. Bras. 2011, 23, 260-270. [CrossRef]

(C) 2017 by the authors. Licensee MDPI, Basel, Switzerland. This article is an open access article distributed under the terms and conditions of the Creative Commons Attribution (CC BY) license (http://creativecommons.org/licenses/by/4.0/). 